\begin{tabular}{|c|l|}
\hline Title & Geology, petrology and tectonic setting of the Late Jurassic ophiolite in Hokkaido, Japan \\
\hline Author(s) & Takashima, Reishi; Nishi, Hiroshi; Y oshida, Takey oshi \\
\hline Citation & $\begin{array}{l}\text { Journal of A sian Earth Sciences, 21(2), 197-215 } \\
\text { https://doi.org/10.1016/S1367-9120(02)00028-7 }\end{array}$ \\
\hline Issue Date & 2002-12-15 \\
\hline Doc URL & http://hdl.handle.net/2115/17184 \\
\hline Type & article(author version) \\
\hline File Information & JAES21-2.pdf \\
\hline
\end{tabular}

Instructions for use 


\section{Geology, petrology and tectonic setting of the late Jurassic ophiolite in Hokkaido, Japan.}

Reishi Takashima $^{\mathrm{a}^{*}}$, Hiroshi Nishi ${ }^{\mathrm{a}}$, Takeyoshi Yoshida ${ }^{\mathrm{b}}$

${ }^{a}$ Department of Earth Science, Kyushu University, Ropponmatsu 4-2-1, Chuo-ku, Fukuoka, 810-8560, Japan.

${ }^{\mathrm{b}}$ Department of Mineralogy, Petrology and Economic Geology Faculty of Science, Tohoku University, Aoba-ku, Sendai, 980-8567, Japan

Received 29 November 2001; accepted

*Corresponding author. Tel.: +81-92-726-4764, Fax: +81-92-726-4764,

E-mail: takagse@mbox.nc.kyushu-u.ac.jp (R. Takashima) 


\section{Abstract}

The Gokurakudaira Formation, which has a north-south zonal distribution within a latest Jurassic greenstone belt in Hokkaido Island, Japan, constitutes the uppermost ultramafic-mafic unit of the Horokanai Ophiolite. The following three different hypotheses on the origin of the ophiolite have been proposed: 1) a mid-oceanic ridge; 2) an oceanic plateau; and 3) an island arc.

The Gokurakudaira Formation can be subdivided into four zones extending north-to-northwest to south-to-southeast, from east (Zone I) to west (Zone IV), based on lithofacies and areal distribution. Zones I and III consist of aphyric tholeiite resembling back-arc basin basalt (BABB), while Zone II is characterized by the coexistence of BABB-like tholeiite along with high-Mg andesite. Zone IV has a different lithology from the other zones, and is composed mainly of picrite and thick sedimentary sequences of island arc tholeiite (IAT) type andesitic subaqueous pyroclastic deposits and terrigenous sediments.

These stratigraphic and petrological characteristics of the Gokurakudaira Formation cannot be explained by the oceanic plateau or mid-oceanic ridge models, but they can be a marginal sea model, as in the Lau Basin. Therefore, we conclude that the Horokanai Ophiolite was formed in a marginal basin above a supra-subduction zone on the margin of the Asian continent in the late Jurassic.

Key words: Greenstone, Ophiolite, Jurassic, Cretaceous, Island arc, Japan 


\section{Introduction}

The tectonic setting of many ophiolites has long been argued, and since Miyashiro (1973) many agree then have affinities with island arcs rather than mid-oceanic ridges. However, the recent discovery of huge greenstone bodies raises the possibility of an origin as oceanic plateaus associated with superplume activity (Hauff et al., 2000; Kimura et al., 1994; Reynaud et al., 1999).

In the axial zone of Hokkaido, the northernmost island of Japan, there is a north-south trending upper Jurassic greenstone belt named the Gokurakudaira Formation (Takashima et al., 2001), the lowermost unit of the Sorachi Group (Figs. 1, 2). The greenstone belt is more than $400 \mathrm{~km}$ long, and $30 \mathrm{~km}$ wide. The Gokurakudaira Formation also constitutes the uppermost ultramafic-mafic unit of the Horokanai Ophiolite (Fig. 2). The tectonic setting of the Horokanai Ophiolite is controversial. It was first thought to be a remnant oceanic crust, because the Gokurakudaira Formation greenstones are broadly similar to Mid-Ocean Ridge Basalts (MORB) (Ishizuka, 1980, 1981, 1985; Kiminami, 1986; Niida, 1992). From more detailed investigations of the petrology, mineralogy and metamorphism in the last decade, Kimura et al. (1994) proposed that the ophiolite represents an accreted Jurassic oceanic plateau, and Arai (1995), Maruyama et al. (1989) and Tamura et al. (1999) a section of an island arc.

In this study, we report new data, which show that the constituents of the Gokurakudaira Formation are not only MORB-like tholeiite, but also picrite, high-Mg basalt-andesite, arc-related volcaniclastic rocks and terrigenous sediments. The aim of this paper is to present new facts on the geology, petrology and geochemical signatures of the Gokurakudaira Formation, and to establish a tectonomagmatic evolution model 
for the Horokanai Ophiolite based on a correlation with other oceanic island arcs.

\section{Regional geologic setting}

The upper Mesozoic formations in the western and central zones of Hokkaido Island are divisible into four tectono-stratigraphic units: the Oshima, Sorachi-Yezo, Kamuikotan, and Hidaka Belts from west to east (Fig. 1). All were developed above a west-dipping subduction zone along the eastern margin of the Asian continent (Okada, 1974). The Gokurakudaira Formation belongs to the Sorachi-Yezo Belt, which consists of a coherent subaqueous volcano-sedimentary succession of late Mesozoic ages. This belt is juxtaposed by two accretionary complexes, named the Oshima Belt to the west, and the Hidaka Belt to the east (Fig. 1). Both belts young to the east, and comprise a sandstone and muddy matrix containing exotic blocks of limestone, greenstone and chert. The former belt contains muddy matrix with an age older than the early Late Jurassic (Ishiga and Ishiyama, 1987), but the age of the latter is earlier than the early Cretacous (Kiyokawa, 1992). The Kamuikotan Metamorphic Belt, which occupies the axial zone of the Sorachi-Yezo Belt, is characterized by high-pressure metamorphic rocks, and has a fault contact with the Sorachi-Yezo Belt. Its protoliths were a muddy matrix with blocks of greenstone, chert and limestone. It is assumed it was a lower Cretaceous accretionary complex, and the metamorphosed western extent of the Hidaka Belt (Kawamura et al., 1998).

The eastern part of the Sorachi-Yezo Belt contains the Horokanai Ophiolite and the Sorachi and Yezo Groups (Fig. 2). The Horokanai Ophiolite is composed of harzburgite, dunite, orthopyroxenite, massive amphibolite, banded amphibolite, and basalt, in ascending order. The basalts of the upper unit of the Gokurakudaira 
Formation are mostly aphyric tholeiite, and their chemical composition resembles that of MORB (Ishizuka, 1981; Niida, 1992; Niida and Kito, 1986). The upper Sorachi Group, which overlies the Horokanai Ophiolite, in places unconformably, represents an oceanic island arc volcano-sedimentary sequence of Tithonian-Barremian age (144-121 Ma; Radiometric ages of each stage boundary are based on Grastein et al., 1995). It is overlain conformably by the Yezo Group, which mainly consists of terrigenous sandstone and mudstone, comprising fore-arc basin deposits ranging from Aptian to Maastrichtian age (121-64 Ma). In contrast, the western part of the Sorachi-Yezo Belt, which corresponds to the Rebun-Kabato Belt of Kiminami et al. (1986), is comprised of the Kumaneshiri and Rebun Groups (Fig. 1) which both contain island arc volcano-sedimentary rocks formed in the Berriasian-Cenomanian age (144-94 Ma).

\section{Stratigraphy and petrology of the Gokurakudaira Formation in central}

\section{Hokkaido Island}

Although a complete sequence of the Horokanai Ophiolite crops out in the Horokanai region located in northern central Hokkaido Island (Fig. 1), the exposures of the Gokurakudaira Formation are confined to a small area. This study focuses on the southern central region of the axial zone of Hokkaido Island, where the Gokurakudaira Formation has the largest exposure. In this region (Fig. 3), the Hidaka and Sorachi-Yezo Belts are shortened owing to arc-arc collision caused by southwestward migration of the Kuril fore-arc sliver since the latest Miocene (Kimura and Tamaki, 1986). The collision resulted in a thrust-fold system which developed noth to south in this region; Ito (2000) estimated that the lateral shortening distance was at least $60 \mathrm{~km}$. 
Therefore, the Gokurakudaira Formation exposes several zones extending NNW to SSE. Each zone is more than $1000 \mathrm{~m}$ thick, and shows little change in lithology. However, a lateral variation across the Mesozoic arc system is indicated by the different compositions in individual zones.

The greenstones of the Gokurakudaira Formation can be divided into three rock types: aphyric basalt, which is the most widespread in the Sorachi-Yezo Belt; picrite; and olivine-phyric basalt-andesite. Based on the combination of greenstone types and their areal distribution, four zones are defined from east (Zone I) to west (Zone IV) (Fig. 3). Zones I and III consist of aphyric basalt, while aphyric basalt and olivine-phyric basalt-andesite coexist in Zone II. Zone IV is composed of picrite, intercalated with a thick sedimentary sequence consisting of andesitic to dacitic volcaniclastic and terrigenous sediments. Takashima et al. (2001) named these volcaniclastic and terrigenous sediments the Hachimoriyama Tuff Member and the Shinpaizawa Sandstone Member, respectively. The greenstones and sedimentary rocks of the Gokurakudaira Formation are metamorphosed to a zeolite and prehnite-pumpellyite facies, but igneous textures are always well preserved.

\subsection{Zone I (Soshubetu-Chiroro area)}

This zone is located on the eastern margin of the Sorachi-Yezo Belt, which means it formed closest to the trench (Fig. 3). The Sorachi Group is exposed in a limited area between two thrusts that strike NNW to SSE, and dip $40-70{ }^{\circ} \mathrm{E}$. The group is generally characterized by overturned, homoclinal sequences that strike NW to SE, $\operatorname{dip} 10-30^{\circ} \mathrm{E}$ and young to the $\mathrm{W}$.

The Gokurakudaira Formation consists of pillowed aphyric basalt and 
subordinate dolerite (Fig. 4). The pillowed basalts are close-packed, consisting of pillow lobes that closely fit with each other. The pillow lobes are cylindrical having few vesicles, and range in size from $20-80 \mathrm{~cm}$ in cross-section. Microscopically, they are entirely aphyric, or sometimes have a few phenocrysts of plagioclase and clinopyroxene (less than $1 \%$ in volume, Fig. 5A). They are hypocrystalline to holocrystalline, but occasionally become glassy and exhibit an intersertal to intergranular texture. The major constituents are idiomorphic plagioclase, granular clinopyroxene, and opaque minerals. Most of the clinopyroxene remains fresh, while the plagioclase has been replaced by albite \pm sericite.

The relationship between the Gokurakudaira Formation and the upper Sorachi Group, named the Chiroro Formation, can be observed in the Chiroro River section. The greenstones of the Gokurakudaira Formation are covered disconformably by a submarine debris flow or debris flow-rock fall deposit comprised of a greenish sandy mudstone matrix and blocks of limestone, chert and greenstone (Kiminami et al., 1985). The greenstone blocks are similar to those of the underlying Gokurakudaira Formation. The green tuffaceous mudstone overlying the debris flow deposit contains many radiolarian fossils of late Valanginian age (137-132 Ma).

\subsection{Zone II (Nunobe area)}

This zone is the second greenstone belt from the east (Fig. 3). The Gokurakudaira Formation is exposed on the west flank of a N-S syncline. The formation dips $30-40^{\circ} \mathrm{E}$, strikes $\mathrm{N}-\mathrm{S}$ and youngs to the E (Fig. 3).

The Gokurakudaira Formation is composed of an aphyric pillowed basalt, and a small amount of olivine-phyric basaltic-andesitic hyaloclastite (Fig. 4). The aphyric 
pillowed basalts are close-packed and poor vesicular structure. Both field and microscopic observations suggests that they are similar to those of Zone I. The basaltic-andesitic hyaloclastites, which constitute the uppermost part of the Gokurakudaira Formation in this area, consist of basaltic-andesitic rubble with a fine-grained matrix. It is matrix-rich, poorly sorted, and contains no recognizable sedimentary structures. The rubble clasts in the hyaloclastites are mostly olivine-phyric andesite and minor olivine-phyric basalt and microdiorite. They are less than $50 \mathrm{~cm}$ in diameter, while the matrix is less than $2 \mathrm{~mm}$ in diameter. The olivine-phyric basalt and andesite contain idiomorphic phenocrysts of olivine $(0.5-1 \mathrm{~mm}$ in diameter, $5-20 \%$ in volume), and microphenocrysts of chrome spinel (Fig. 5B). Olivine occasionally encloses the chrome spinel. The groundmass, which mainly consists of glass, idiomorphic plagioclase and granular clinopyroxene with a subordinate amount of opaque minerals, is hypocrystalline with an intersertal to intergranular texture. Some samples contain abundant vesicular material, up to $10 \%$ in volume. Plagioclase is altered to albite, and most olivine to serpentine. Microdiorite rubble in the hyaloclastite is mainly composed of plagioclase, clinopyroxene, cummingtonite, olivine, and opaque minerals, in order of decreasing abundance. Most cummingtonite remains fresh and contains smaller idiomorphic olivine inclusions. The matrix in hyaloclastite (less than 1 $\mathrm{mm}$ in diameter) consists of bubble-wall-shaped glassy particles and phenocryst fragments derived from olivine-phyric lava.

The Gokurakudaira Formation is intruded by a micro-monzonite sill which mainly consist of plagioclase with subordinate clinopyroxene, potassium-felsper, opaque minerals and hornblende. The sill is unconformably overlain by a volcani-sedimentary sequence containing abundant radiolaria of Valanginian age 
(137-132 Ma) (Minoura et al., 1982).

\subsection{Zone III (Nae Range and Eastern Yubari Range areas)}

This zone consists of the third (the Nae Range) and fourth (eastern slope of the Yubari Range) greenstone belts. The Sorachi Group in the Nae Range generally strikes $\mathrm{N}-\mathrm{S}$, is vertically inclined, and homoclines young westward. On the other hand, in the eastern slope of the Yubari Range, the Sorachi Group strikes N-S, dips $40^{\circ} \mathrm{E}$, and homoclines young eastward (Fig. 3).

The Gokurakudaira Formation in this zone mainly consists of pillowed basalt and minor basaltic hyaloclastite (Fig. 4). The pillowed basalts show a close-packed structure, and resembles those of Zone I. The hyaloclastites are composed of basalt rubble and a glassy matrix. They are matrix-supported and/or clast-supported, and have no sedimentary structure. Rubble clasts in the hyaloclastites are usually less than $40 \mathrm{~cm}$ in diameter, with the largest reaching $70 \mathrm{~cm}$. Under the microscopic, all the basalts are aphyric, and similar to those of Zones I and II.

The Gokurakudaira Formation is conformably covered by tuffaceous mudstone which is frequently intercalated with felsic tuff beds. The mudstone yields abundant radiolaria of late Tithonian age (146-144 Ma) (Kito, 1987).

\subsection{Zone IV (Western Yubari Range area)}

In the Sorachi-Yezo belt, this zone occupies the westernmost exposure of the Sorachi Group, which is generally characterized by vertically inclined, occasionally overturned, homoclinal sequences that strike $\mathrm{N}-\mathrm{S}$ and young westward. The Gokurakudaira Formation occurs on the western side of the Yubaridake thrust and 
along the backbone of the Yubari Range (Fig. 3).

The Gokurakudaira Formation of this zone has a completely different lithology from that of the other zones. It mainly consists of a picritic pillow lava and a hyaloclastite with local intercalations of thick sediments belonging to the Hachimoriyama Tuff Member and Shinpaizawa Sandstone Member (Figs. 4, 6). Most pillows are closely packed as in the other zones. The hyaloclastites consist of basaltic rubble clasts less than $30 \mathrm{~cm}$ in diameter, and a fine-grained matrix made up of glass shards which are less than $2 \mathrm{~mm}$ in diameter. The pillow lavas predominate in the northern area, whereas the hyaloclastites are dominant in the southern area.

Under the microscope, the picrites contain abundant idiomorphic phenocrysts of olivine (less than $2 \mathrm{~mm}$ in diameter, $10-70 \%$ in volume) and chrome spinel (less than $0.5 \mathrm{~mm}$ in diameter, less than $1 \%$ in volume) (Fig. 5C). Most olivine is altered to serpentine, some contain fresh microphenocrysts of chrome spinel. A few fresh olivine phenocrysts show kink-bands. The content of olivine phenocyrsts decreases upwards. The groundmass is usually hypocrystalline to holocrystalline, is occasionally glassy with an intersertal to intergranular texture, and mainly consists of granular clinopyroxene (less than $0.2 \mathrm{~mm}$ in diameter), and idiomorphic plagioclase (less than $0.4 \mathrm{~mm}$ in diameter). Most clinopyroxene is granular with minor dendritic forms. The clinopyroxene is fresh, but all of the plagioclase is altered to albite \pm sericite.

The Gokurakudaira Formation is covered conformably by a red mudstone containing abundant radiolarian fossils, which indicate a Berriasian age (144-137 Ma) (Takashima et al., 2001).

\subsubsection{Hachimoriyama Tuff Member}

The Hachimoriyama Tuff Member is interbedded with the picrite. It is 
restricted to the southern area, it pinches out northwards (Fig. 3), it has a thickness of up to $150 \mathrm{~m}$, and is mainly composed of pale-green tuffaceous mudstone with interbedded andesitic and dacitic volcaniclastic deposits (Figs. 4, 6).

The pale-green tuffaceous mudstone contains abundant radiolarian fossils indicating an age from the latest Kimmeridgian to early Berriasian (153-142 Ma) (Takashima et al., 2001). Sometimes, felsic tuff beds ranging in thickness from $10 \mathrm{~cm}$ to $1 \mathrm{~m}$ are intercalated with mudstone.

Recently, 50m-thick subaqueous pyroclastic flow deposit was confirmed in the lower part of this member (Takashima et al., 2001). It consists of two successions in which the beds thin upwards. The lower and upper successions are $20 \mathrm{~m}$ and $30 \mathrm{~m}$ thick, respectively. Although the thickness of each bed in the basal part of each succession varies from $50 \mathrm{~cm}$ to $4 \mathrm{~m}$, it is $5-10 \mathrm{~cm}$ thick in the upper part. The beds mainly consist of andesite and/or dacite fragments (less than $4 \mathrm{~mm}$ in diameter), pumice, crystals derived from volcanic rocks, and minor rip-up-clasts of tuffaceous mudstone. Under the microscope, the subaqueous pyroclastic flow deposits are different in the two successions. The lower one is dacitic, whereas the upper one is andesitic. The dacitic subaqueous pyroclastic deposit mainly consists of idiomorphic plagioclase, corroded quartz, and dacite fragments, admixed with subordinate amounts of idiomorphic clinopyroxene, opaque minerals, and pumice, in order of decreasing abundance (Fig. 5D). The dacite fragments contain idiomorphic phenocrysts of plagioclase (less than 3 $\mathrm{mm}$ in diameter), corroded quartz (less than $2 \mathrm{~mm}$ in diameter), and clinopyroxene (less than $2 \mathrm{~mm}$ in diameter). The groundmass is glassy with a hyalopilitic texture and contains a few grains of idiomorphic plagioclase, granular quartz, and opaque minerals (less than $0.1 \mathrm{~mm}$ in diameter). All the plagioclase has been altered to albite \pm sericite. 
The andesitic deposit in the upper succession is poorly sorted, and is made of plagio-phyric andesite fragments (less than $1 \mathrm{~cm}$ in diameter), idiomorphic plagioclase, and clinopyroxene (both less than $4 \mathrm{~mm}$ in diameter), in order of decreasing abundance (Fig. 5E). There are also subordinate amounts of pumice and opaque minerals, hornblende, and exotic fragments of dolerite and picrite. The plagio-phyric andesite fragments contain idiomorphic phenocrysts of plagioclase $(0.5-4 \mathrm{~mm}$ in diameter, $10-20 \%$ in volume), and minor clinopyroxene and hornblende (less than $2 \mathrm{~mm}$ in diameter, $5 \%$ in volume). The phenocrysts of plagioclase are occasionally altered to albite \pm sericite, and are sometimes glomeroporphyritic in texture. The groundmass is hypocrystalline to glassy, and shows an intersertal to hyalopilitic texture. It consists of idiomorphic plagioclase and granular opaque minerals. Furthermore, the uppermost part of this sequence as a whole is intercalated with some 10 or more beds of calcareous turbidite which mainly consists of calcareous fragments, admixed with subordinate ooids, plagioclase, clinopyroxene, hornblende, and andesite fragments (less than $2 \mathrm{~mm}$ in diameter).

The andesitic crystalline tuff beds are intercalated in the uppermost part of this member. They exhibit a thinning-bed upward succession varying in thickness from 5-30 cm, and consist of idiomorphic minerals such as plagioclase, hornblende, clinopyroxene, and opaque minerals. Locally there are common andesitic fragments.

\subsubsection{Shinpaizawa Sandstone Member}

The Shinpaizawa Sandstone Member is also restricted to the southern area, and thins and pinches out northward (Fig. 3). It has a total thickness of more than $82 \mathrm{~m}$, and conformably overlies the Hachimoriyama Tuff Member (Fig. 6).

The member consists of sandstone-dominant alternating beds of sandstone and 
mudstone. The sandstone beds are of arkosic turbidite which contain two successions in which bears thicken upward. Though the thickness of each bed is $20-30 \mathrm{~cm}$ in the basal part of the succession, it becomes $2 \mathrm{~m}$ thick in the upper part. Microscopically, the sandstone is well sorted, and is a medium to coarse-grained lithic or feldspathic arenite which mainly consist of rounded quartz and plagioclase (less than $2 \mathrm{~mm}$ in diameter), and subordinate rock fragments, carbonaceous matter, biotite, microcline, muscovite, and zircon (Fig. 5F). Although most quartz grains show wavy extinction, some are partly corroded and show straight extinction. The rock fragments are mainly composed of rhyolite, granite and spherulite, with rare muscovite-quartz schist and hornfels which exhibits a granoblastic texture. Takashima et al. (2001) considered that the sandstone was derived from the Asian continent from an analysis of paleocurrent directions and the composition of the sandstone.

In contrast, the mudstone is dark gray, is less than $10 \mathrm{~cm}$ thick and contains abundant carbonaceous matter, but no fossils.

\section{Chemistry of the igneous rocks and minerals}

In order to construct a tectonomagmatic model for this ophiolite, 53 representative volcanic rock and volcanic fragment samples were analyzed for major and trace elements. 13 of them were also analyzed for rare earth elements (REE) (Table 1). These rocks have been metamorphosed in the zeolite and prehnite-pumpellyite facies with or without hydrothermal alteration, but the igneous textures are always well preserved.

Of these volcanic samples, the olivine-phyric basalt-andesite of Zone II and the 
picrite of Zone IV contain abundant relict chrome spinel, chemistry of which plays an important role in understanding origin and tectonic setting. In order to clarify the character of the mantle source of the Gokurakudaira Formation, chrome spinels were analyzed from five samples from the Zone II high-Mg basalt-andesite and the Zone IV picrite (Table 2).

\subsection{Analytical techniques}

Major and trace elements were determined using X-ray fluorescence spectrometry (XRF) at the Faculty of Education, Fukushima University. REE data were obtained using an inductively-coupled plasma mass spectrometer (ICP-MS) at the Geological Survey of Japan. In the ICP method, $100 \mathrm{mg}$ of powdered sample was dissolved twice in $5 \mathrm{ml}$ of ultrapure hydrofluoric acid (HF), and $3 \mathrm{ml}$ of ultrapure $\mathrm{HNO}_{3}$ and ultrapure hydrochloric acid $(\mathrm{HCl})$. The solution was diluted with $5 \mathrm{ml}$ of concentrated ultra-pure nitric acid $\left(\mathrm{HNO}_{3}\right)$ and double-distilled Milli-Q-water to adjust the total volume to exactly $100 \mathrm{ml}$. $\mathrm{FeO}$ was analyzed by titration, and the $\mathrm{H}_{2} \mathrm{O}^{+}$ contents were determined after ignition.

The chemical composition of the chrome spinels was determined using an electron probe micro-analyzer (EPMA) at the Department of Earth and Planetary Sciences, Kyushu University (Table 2). The cationic fractions of $\mathrm{Mg}, \mathrm{Fe}^{2+}, \mathrm{Al}, \mathrm{Cr}$ and $\mathrm{Fe}^{3+}$ were calculated by assuming spinel stoichiometry after allotting all of the Ti to the ulvospinel molecule.

\subsection{Results}

The volcanic rock and volcanic fragments of the Gokurakudaira Formation are 
classified into four types based on their geochemical and petrographic features which are as follows. Type 1: MORB-like aphyric tholeiite; type 2: high-Mg basalt-andesite; type 3: depleted picrite; type 4: arc-type volcanic fragments. These terms will be used for the following geochemical discussion.

\subsubsection{Type 1. Aphyric tholeiite}

This type is represented by the aphyric tholeiite of Zones I, II and III, which has the most extensive distribution in the Gokurakudaira Formation. Aphyric tholeiites of Zones II and III have a unfractionated composition in the range from 47 to $52 \%$ for $\mathrm{SiO}_{2}$ and 1-2 for $\mathrm{FeO}^{*} / \mathrm{MgO}$, whereas those of Zone I represent a more fractionated composition of up to $55 \%$ for $\mathrm{SiO}_{2}$ and 3 for $\mathrm{FeO} * \mathrm{MgO}$ (Fig. 7A and B). The aphyric tholeiites are MORB-like in the discrimination diagrams of Fig. 7D and E, but show some supra-subduction zone (SSZ) signature with lower $\mathrm{TiO}_{2}$ relative to $\mathrm{MORB}$ at a given value of $\mathrm{FeO} * \mathrm{MgO}$ (Fig. 7C). In Fig. 7C, the trend of type 1 samples is closer to that of back-arc basin basalt (BABB) rather than to that of MORB.

Fig. 8A shows the N-MORB-normalized incompatible trace element abundance patterns of type 1 rocks. Although the unfractionated samples resemble MORB in showing flat patterns, the patterns of the fractionated samples (SS08) of Zone I are clearly different from the MORB pattern, and exhibit a SSZ signature having moderate large-ion lithophile element (LILE) enrichment, and $\mathrm{Nb}$ and Ta depletion.

\subsubsection{Type 2. High-Mg basalt-andesite}

The type 2 rocks, which are olivine-phyric basalt and andesite of Zone II, demonstrate a clear calc-alkaline differentiation trend, and is distinct from the other volcanic rocks of the Gokurakudaira Formation (Fig. 7A). They are very primitive $(\mathrm{FeO} * \mathrm{MgO}<1)$, and have a highly depleted chemical composition that has many of 
the characteristics of high-Mg andesites. Their $\mathrm{SiO}_{2}$ contents are as high as $56 \%$, but they also have high $\mathrm{MgO}(11-18 \%)$, Ni (242-700 ppm), Cr (435-1605 ppm), and $\mathrm{CaO} / \mathrm{Al}_{2} \mathrm{O}_{3}$ ratios $(0.89-2.01)$. These features are similar to that of a high-Ca boninite (Crawford et al. 1989). However, the absence of orthopyroxene, the high $\mathrm{TiO}_{2}$ $(0.4-1.2 \%)$ value in whole rock, and the low $\mathrm{Cr} \#(\mathrm{Cr} /(\mathrm{Cr}+\mathrm{Al})=0.4-0.64)$ in chrome spinel are not consistent with boninite.

As shown by the discrimination and spider diagrams in Figs. $7 \mathrm{E}$ and $8 \mathrm{~B}$, they are highly depleted both in terms of LILE and high field strength elements (HFSE) relative to N-MORB. The composition of the chrome spinels plot in the island arc field (Fig. 9).

\subsubsection{Type 3. Picrite}

This type is represented by the picrites of Zone IV which are very primitive, because $\mathrm{FeO} * \mathrm{MgO}$ is $<1.5$, and because they show a depleted composition like type 2 rocks. However, the picrites are distinctive in having a lower $\mathrm{SiO}_{2}$ content (42-50\%) and a higher $\mathrm{Al}_{2} \mathrm{O}_{3}$ content (up to $14.5 \%$ ) than the type 2 rocks. Notable are the very high $\mathrm{MgO}$ (up to $30.3 \%$ ), Ni (up to $1648 \mathrm{ppm}$ ) and $\mathrm{Cr}$ (up to $3443 \mathrm{ppm}$ ) contents. There is a general trend of upward increasing $\mathrm{SiO}_{2}$ and decreasing $\mathrm{MgO}$ contents; that is, samples of the lowermost horizon of the Gokurakudaira Formation reach up to $31.8 \% \mathrm{MgO}$ and $42 \% \mathrm{SiO}_{2}$, whereas those of the uppermost part have $7-12 \% \mathrm{MgO}$ and $47-50 \% \mathrm{SiO}_{2}$ (Fig. 7A). This trend is consistent with the petrographic evidence that olivine phenocrysts decrease upward.

The N-MORB-normalized incompatible trace element abundance patterns show that they are highly depleted both in terms of LILE and HFSE relative to N-MORB (Fig. 8C), and that these characteristics are similar to those of Lau Basin picritic glass, as 
reported by Falloon et al., (1999). The incompatible trace elements tend to increase upwards. The chemical compositions of the chrome spinels plot in the same fields on the type 2 rocks representing an island arc.

\subsubsection{Type 4. Arc-type volcanic fragment}

This type represents an essential fragment of the andesitic volcaniclastic breccia of the Hachimoriyama Tuff Member. The fragment (sample WY21) is andesite, containing phenocrysts of plagioclase and minor clinopyroxene and hornblende. The spider diagrams of incompatible trace element abundance patterns clearly exhibit a SSZ signature having LILE enrichment and depletion in HFSE, especially $\mathrm{Nb}$ and $\mathrm{Ta}$ relative to N-MORB (Fig. 8D).

\section{Discussion}

\subsection{Tectonic setting of the Horokanai Ophiolite}

As mentioned above, there are three published tectonic models for the origin of the Horokanai Ophiolite: (i) a mid-oceanic ridge (Ishizuka, 1980, 1981; Kiminami, 1986; Niida, 1992; Niida and Kito, 1986); (ii) an oceanic plateau (Kimura et al., 1994); and (iii) an oceanic island arc (Maruyama et al., 1989; Tamura et al., 1999). The first two hypotheses are based mainly on the geological and geochemical evidence of the Gokurakudaira Formation, whereas the last is based on mineral chemistry of the peridotite and analysis of the metamorphic facies.

Ishizuka $(1980,1981)$ described the lithology and petrology of the Horokanai Ophiolite in detail, and concluded it was derived from a mid-oceanic ridge for the following four reasons: 1) the greenstone unit of the ophiolite is overlain by chert; 2) no 
terrigenous deposits are intercalated with the greenstone unit and overlying sediments; 3) the whole rock chemistry of the greenstones has a close affinity with MORB; and 4) the chemical composition of chrome spinel in the greenstones also resembles that of MORB. Based on these facts, Niida and Kito (1986) and Kiminami et al. (1986) proposed a tectonic model in which the ophiolite was trapped behind a trench of a hypothetical westward-dipping subduction zone generated on the Jurassic seafloor off the Asian continental margin. In contrast, Kimura et al. (1994) presumed the Gokurakudaira Formation belongs to the same accreted exotic block as the greenstone blocks of the Kamuikotan Metamorphic Belt, because of their identical greenstone age and together then belong to an oceanic plateau. Although the greenstones of the Gokurakudaira Formation were thought to have been generated from a depleted mantle source (Niida, 1992), enriched plume source components were found in the greenstones of the Kamuikotan Metamorphic Belt. The coexistence of these two sources enables both to have an input into the plume source melt into the depleted oceanic lithosphere, and this explained why the plateau formed at a low-latitude in central Panthalassa during the Tithonian (151-144 Ma), and resulted in accretion along the northern Asian continental margin in the Aptian (121-112 Ma). In contrast, Maruyama et al. (1989) concluded that it was a marginal sea or fore-arc ophiolite because of the presence of prenite-pumpellyite facies which is generally not found in mid-oceanic ridges. Arai (1995) and Tamura et al. (1999) also suggested it might be a fore-arc ophiolite, because the Cr\# range of the chrome spinel and forsterite contents of the olivine in the peridotite were much higher than those of MORB, and close to those of fore-arc peridotites.

The Gokurakudaira Formation has been recognized as the only unfractionated type-1-aphyric tholeiite covered by abyssal sediments (Ishizuka, 1980, 1981; Niida, 
1992). Hence, the tectonic models, proposed above, were interpreted only from the viewpoint of the geological and geochemical characteristics of the type 1 tholeiite. However, we have identified two new types of volcanic rock, i.e., picrite and high-Mg basalt-andesite, as well as intercalations of thick sedimentary sequences (Hachimoriyama Tuff and Shinpaizawa Sandstone Members) in the Gokurakudaira Formation. Therefore, a model for the tectonic setting and evolution of the ophiolite must account for the fundamental stratigraphic and petrological characteristics of the sequence, including: (1) development of (MORB-like) BABB-type lavas; (2) eruption of the high-Mg basalt-andesite onto the BABB-type lava; and (3) formation of effusive picrites associated with arc-type andesitic-dacitic submarine pyroclastic deposits and terrigeous turbidites in a back-arc.

The type 1 tholeiites are similar to MORB to a large extent, but are distinguished in having a lower $\mathrm{TiO}_{2}$ content similar to the Mariana Trough and Lau Basin basalts. Hawkins (1995) pointed out that the lower Ti value in BABB relative to MORB results from elevated $\mathrm{fO}_{2}$ in parental melts, and their more oxidizing environment may be due to a higher water content. Furthermore, we have identified fractionated aphyric tholeiites with typical SSZ trace element signatures (moderate LILE enrichment and depletion of $\mathrm{Nb}$ and $\mathrm{Ta}$ ) in Zone I. The back-arc basin basalts from the Lau Basin and the Mariana Trough are obviously different from MORB, especially for the more fractionated samples, although they are MORB-like in most other essential aspects (Hawkins, 1995).

Since the high-Mg andesite of Zone II was more or less affected by alteration, having a high $\mathrm{Na} 2 \mathrm{O} / \mathrm{K} 2 \mathrm{O}$ ratio (46-103), there is a possibility that the high-silica content of type 2 rocks results from alteration. However, if one assumes that type 2 
rocks did not suffer a much mobility in $\mathrm{SiO}_{2}$, the occurrence of the type 2 rocks provides strong tectonic and petrological constraints on magma genesis. Many experimental results show that high-Mg andesitic melts may be formed by direct partial melting of the upper mantle under hydrous and low-pressure conditions (Tatsumi, 1981, 1982; Tatsumi and Maruyama, 1989). From a geological viewpoint, Tatsumi and Maruyama (1989) compiled the following two tectonic constraints on high-Mg andesite magma generation: (1) in fore-arc regions, where young or hot oceanic lithosphere subducts; and (2) marginal or back-arc opening took place just before the high-Mg andesite magmatism. These features are consistent with those of Zone II, where the high-Mg andesite erupted onto the BABB-type lava at the trench-side of the Sorachi-Yezo Belt. Tamura et al. (1999) extrapolated that high-Mg melts had been generated in the Sorachi-Yezo Belt because the dunite and harzburgite of the Horokanai Ophiolite in the Horokanai area have an extremely high Cr\# (0.64-0.92) in chrome spinels and a high forsterite content $(\mathrm{Fo}=91.9-94.0 \mathrm{~mol} \%)$ in olivine. The occurrence of high-Mg andesite in Zone II is consistent with these extrapolations.

Zone IV mainly consists of picrite, and is characteristically filled with thick turbiditic deposits derived from both the arc and the Asian continent to the west. These thick interstratified terrigenous and volcaniclastic turbiditic successions commonly occur in the fore-arc, intra-arc, or back-arc regions near a continent (e.g., the Okinawa Trough and the Coast Range Ophiolite). Furthermore, the olivine phenocrysts of the picrites show kink-bands, which suggest that they are xenocrysts derived from peridotites. According to Niida and Kito (1999), the chemical compositions of the olivine and chrome spinel $(\mathrm{Fo}=90.4-93.9 \mathrm{~mol} \%$; $\mathrm{Cr} \#=57-64.4)$ in the type 3 picrites are within the range of those in the harzburgite of the Horokanai ophiolitic peridotite, 
which accordingly were considered to be fore-arc in origin (Tamura et al., 1999).

The oceanic plateau and mid-oceanic ridge models cannot account for the above-mentioned factors. Instead, the island arc model can explain these factors well. Although the greenstones of the Kamuikotan Metamorphic Belt and the Gokurakudaira Formation were formed at the same time, they are quite different in lithology, especially because the Gokurakudaira Formation of Zone IV contains terrigenous sediments. As the blocks in the Kamuikotan Belt consist of chert, basalt, and limestone without terrigenous materials, the lithology of the Gokurakudaira Formation does not support the assumption of Kimura et al. (1994) that the greenstones of the Kamuikotan Metamorphic Belt and the Gokurakudaira Formation have the same origin. Therefore, the possibility that the greenstone blocks of the Kamuikotan Metamorphic Belt are derived from an oceanic plateau is still possible, but it should be discussed separately.

The lithological variation across the arc in the Gokurakudaira Formation shows that the arc-derived sedimentary rocks were deposited only in a back-arc area, regardless of the development of BABB-type lava most of over this region. In this case, the Gokurakudaira Formation can be best explained by the fore-arc model of the Lau Basin, where rifting and seafloor spreading were induced along the fore-arc region. The application of this model is also supported by the fact that the peridotite of this ophiolite resembles those of fore-arc regions. Therefore, in the same way as the Lau Basin, in the first stage of development of the Gokurakudaira Formation, rifting and seafloor spreading took place in a fore-arc area. Then, in the next stage of seafloor opening, high-Mg andesite magma was generated, and a remnant arc became inactive as the arc front migrated eastwards. 


\subsection{Tectonomagmatic evolution in Hokkaido during the Late Jurassic to early}

\section{Cretaceous}

Here we present a tectonomagmatic model that satisfies the petrological and stratigraphical constraints from the Gokurakudaira Formation. The evolution of the ophiolite is divisible into the following three stages: 1) rifting along the fore-arc; 2) seafloor spreading; and 3) post-spreading (Fig. 10).

\subsubsection{Stage 1 (late Kimmeridgian: 153-151 Ma)}

Initial rifting probably occurred mainly in Zone IV, where the oldest sediment in this region is situated on the basaltic basement. The radioralian data of the oldest sediment show that the basin rifting begun by about the late Kimmeridgian. The rifting or extension of crust along the fore-arc would have caused an influx of depleted MORB-like mantle, because the chemical composition of the type 3 picrite and type 1 tholeiite resembles that of MORB in many respects. Eruption of the olivine-rich picrite (up to $70 \%$ in volume) at the initial stage of rifting may be related to the MORB-like melt/conduit of fore-arc peridotite interaction, and may also result in the mixtures of MORB-like melt and olivine xenocrysts of a fore-arc peridotite. As rifting continued, the content of olivine xenocrysts decreased, and instead, type 1 tholeiites were the dominant eruption products. A similar situation took place in the Lau Basin where highly depleted picritic glass was recovered from the Peggy Ridge, where the first magmas erupted as the Lau Basin opened (Falloon et al., 1999). The occurrence of picrites from a back-arc has also been reported in the Ryukyu arc, and was considered by Ito and Shiraki (1999) to be intimately related to the opening of the Okinawa Trough. Hence, we infer that the zone IV picrite had erupted from a spreading center at an initial stage of rifting in the wake of the influx of MORB-like mantle. 


\subsubsection{Stage 2 (Tithonian: 151-144 Ma)}

The second stage of seafloor spreading was predictably followed by rifting, and type 1 tholeiite erupted widely in the Sorachi-Yezo Belt. Seafloor spreading was initiated in the Tithonian, because most type 1 tholeiites in Hokkaido are covered by Tithonian deep sea sediments (e.g., Kito et al., 1986). The crust, formed earlier in the opening process, is characterized by the coexistence of arc-like enriched lava and MORB-like depleted lava, as seen in Zone I, but it reached a MORB-like uniform composition as the opening progressed. It is possible that the earliest eruption effectively stripped out the incompatible elements, and the large volume of melt subsequently may have come largely from a more depleted, MORB-like mantle source.

The remnant arc, which had been left behind by the rift basin, became inactive as the sea floor developed, and the trench migrated eastward, characterized by intermediate to felsic volcanism. The presence of ooids in the volcaniclastic sandstones indicates that the remnant arc was subject to localized shoaling at least by the Tithonian.

Nakanishi et al. (1992) showed that a drastic change in spreading rate occurred in all the Mesozoic Pacific spreading systems. They suggested that the reorganization of the plate configuration in the Pacific Ocean occurred at the same time as changes in continental rifting in other parts of the world. Our data of the latest Jurassic rifting along the Asian continent supports their suggestion.

\subsubsection{Stage 3 (early Berriasian: 144-142 Ma)}

After the spreading phase, the high-Mg basalt-andesite erupted onto the newly formed BABB crust. As pointed out by Tatsumi and Maruyama (1989), the eruption of high-Mg andesite after a back-arc opening is a common characteristic of arc evolution, 
and the same situation can be seen in the Izu-Bonin arc and the Ryukyu arc (e.g. Shinjo, 1999). Moreover, a large volume of terrigenous turbidites derived from the Asian continent was deposited in the back-arc. Rapid subsidence of the remnant arc may have admitted an influx of terrigenous turbidites into the rifted basin. This is similar to the Ryukyu arc with regard to the presence of a continent behind an arc.

After Stage 3, a new arc was constructed on the basaltic basement, which is represented by the upper Sorachi Group.

\section{Conclusions}

1. A north-south trending Late Jurassic greenstone belt named the Gokurakudaira Formation constitutes the uppermost unit of the Horokanai Ophiolite, and is divided into four zones from east (Zone I) to west (Zone IV) on the basis of lithofacies and areal distribution.

2. Zones I and III are composed of aphyric tholeiite, whereas Zone II is characterized by the occurrence of high-Mg basalt-andesite above aphyric tholeiite. Zone IV consists of picrite locally intercalated with thick sedimentary sequences of andesitic-dacitic volcaniclastic and terrigenous deposits. The volcaniclastic sequence is named the Hachimoriyama Tuff Member, and the terrigenous sequence the Shinpaizawa Sandstone Member.

3. The aphyric tholeiite is close to BABB, having a SSZ signature, especially for the more fractionated samples. The high-Mg basalt-andesite, which resembles a high-Ca boninite, is highly depleted in terms of LILE and HFSE, relative to MORB. The picrite is also highly depleted in LILE and HFSE. The volcanic fragments of the Hachimoriyama Tuff Member clearly have a SSZ signature, showing LILE 
enrichment, and depletion in HFSE, especially in $\mathrm{Nb}$ and $\mathrm{Ta}$, relative to N-MORB.

4. Our newly identified lithological and stratigraphical variations in the Gokurakudaira Formation are close to those of the Lau Basin and Ryukyu arc, which suggests that the tectonic setting of the Horokanai Ophiolite was on a west-dipping SSZ on the margin of the Asian continent.

5. In the late Kimmeridgian, the initial rifting with the eruption of picrite of Zone IV occurred along the fore-arc region located off the eastern margin of the Asian continent, with the old arc left behind this rift basin. Seafloor spreading followed the rifting, and caused the development of BABB-type lava. After the spreading, high-Mg basalt-andesite erupted onto the BABB crust.

\section{Acknowlegments}

The authors thank Prof. Tsunemasa Saito, Tohoku University, Prof. Keiichi Shiraki, Yamaguchi University, Prof. Harutaka Sakai, Kyushu University and Dr. Hiroshi Kojitani, Gakushuin University for their criticism and constructive comments. Prof. Ken-ichi Manabe of Fukushima University kindly permitted us to use XRF facilities. Special thanks are due to Dr. Jun-ichi Kimura, Shimane University, Dr. Yoshitaka Nagahashi, Fukushima University, Prof. Hotaka Kawahata, Geological Survey of Japan, Prof. Satoshi Kanisawa, Dr. Ken-ichi Ishikawa, Tohoku University, Dr. Masato Nohara, Rena Maeda and Mitsuru Yamamura, Geological Survey of Japan for assistance with chemical analyses and for many helpful suggestions. We acknowledge Dr. A. J. Barber, Prof. Brian Windley and Prof. Bor-ming jahn for critically reviewing the manuscript.

\section{References}


Arai, S., 1992. Chemistry of chromian spinel in volcanic rocks as a potential guide to magma chemistry. Mineralogical Magazine 56, 173-184.

Arai, S., 1995. Oceanic lithosphere and ophiolites; Their similarities and differences. Journal of Geography Japan 104, 361-380 (in Japanese with English Abstract). Crawford, A. J., Falloon, T. J., Green, D. H., 1989. Classification, petrogenesis and tectonic setting of boninites. In: Crawford, A. J. (Eds.), Boninites and Related Rocks. Unwin Hyman, London, pp. 1-49.

Falloon, T.J., Green, D.H., Jacques, A.L., Hawkins, J.W., 1999. Refractory magmas in back-arc basin settings-experimental constraints on the petrogenesis of a Lau Basin example. Journal of Petrology 40(2), 255-277.

Grastein, F. M., Agterberg, F. P., Ogg, J. G., Hardenbol, J., Veen, P., Thierry, J., Huang, Z., 1995. A Triassic, Jurassic and Cretaceous time scale. In: Berggren, W. A., Kent, D. V., Aubry, M., Hardenbol, J. (Eds), Geochronology, time scales and global stratigraphic correlation. SEPM special publication 54, pp. 95-126.

Hauff, F., Hoernle, K., Tilton, G., Graham, D.W., Kerr, A.C., 2000. Large volume recycling of oceanic lithosphere over short time scales: geochemical constraints from the Caribbean Large Igneous Province. Earth and Planetary Science Letters 174, 247-263.

Hawkins, J.M., 1995. Evolution of the Lau Basin-Insight from ODP Leg 135. In: Taylor, B., Natland, J. (Eds.), Active Margins and Marginal Basins of the Western Pacific. American Geophysical Union, Geophysical Monograph 88, pp. $125-173$

Ishiga, H., Ishiyama, D., 1987. Jurassic accretionary complex in the Kaminokuni Terrane, southwestern Hokkaido, Japan. Mining Geology 37, 381-394. 
Ishizuka, H., 1980. Geology of the Horokanai ophiolite in the Kamuikotan tectonic belt, Hokkaido, Japan. Journal of the Geological Society of Japan 86, 119-134 (in Japanese with English Abstract).

Ishizuka, H., 1981. Geochemistry of the Horokanai ophiolite in the Kamuikotan tectonic belt, Hokkaido, Japan. Journal of the Geological Society of Japan 87, 17-34.

Ishizuka, H., 1985. Prograde metamorphism of the Horokanai Ophiolite in the Kamuikotan zone, Hokkaido, Japan. Journal of Petrology 26, 391-417.

Ito, J., Shiraki, K., 1999. Picrite basalts from the Pliocene Uegusukudake Formation in Kume-jima, Ryukyu Islands. Journal of the Geological Society of Japan 105, 810-813 (in Japanese with English Abstract).

Ito, T., 2000. Crustal structure of the Hidaka collision zone and its foreland fold-and-thrust belt, Hokkaido, Japan. Journal of the Japanese association for petroleum technology 65, 103-109 (in Japanese with English Abstract).

Kawamura, M., Nakagawa, M., Kato, M., the Kamuikotan Belt Research Group, 1998. Geologic structure of the metamorphosed Mesozoic accretionary complex in the Sorachi-Yezo belt, central Hokkaido, Japan. Unit classification of the Biei Complex and proposal of Oichan Nappe. Chikyu-Kagaku 52, 433-452 (in Japanese with English Abstract).

Kiminami, K., 1986. Cretaceous tectonics of Hokkaido and the environs of the Okhotsk Sea. In: Editorial committee of geology and tectonics of Hokkaido (Eds.), Geology and Tectonics of Hokkaido. Monograph of the Association for the Geological Collaboration in Japan 31, pp. 403-418 (in Japanese with English Abstract). 
Kiminami, K., Komatsu, M., Niida, K., Kito, N., 1986. Tectonic divisions and stratigraphy of the Mesozoic rocks of Hokkaido, Japan. In: Editorial committee of geology and tectonics of Hokkaido (Eds.), Geology and Tectonics of Hokkaido. Monograph of the Association for the Geological Collaboration in Japan 31, pp. 1-15 (in Japanese with English Abstract).

Kiminami, K., Kontani, Y., Miyashita, S., 1985. Lower Cretaceous strata covering the abyssal tholeiite (The Hidaka western greenstone belt) in the Chiroro area, central Hokkaido, Japan. Journal of the Geological Society of Japan 91, 27-42.

Kimura, G., Sakakibara, M., Okamura, M., 1994. Plumes in central Panthalassa? Deductions from accreted oceanic fragments in Japan. Tectonics 13, 905-916. Kimura, G., Tamaki, K., 1986. Oblique subduction and collision. Geology 14, 404-407. Kito, N., Kiminami, K., Niida, K., Kanie, K., Watanabe, T., Kawaguchi, M., 1986. The Sorachi Group and the Yezo Supergroup: Late Mesozoic ophiolites and forearc sediments in the axial zone of Hokkaido. In: Editorial committee of geology and tectonics of Hokkaido (Eds.), Geology and Tectonics of Hokkaido. Monograph of the Association for the Geological Collaboration in Japan 31, pp. 81-96 (in Japanese with English Abstract).

Kito, N., 1987. Stratigraphic relation between greenstones and clastic sedimentary rocks in the Kamuikotan Belt, Hokkaido, Japan. Journal of the Geological Society of Japan 93, 21-35 (in Japanese with English Abstract).

Kiyokawa, S., 1992. Geology of the Idonnappu Belt, Central Hokkaido, Japan: Evolution of a Cretaceous accretionary complex. Tectonics 11, 1180-1206. Maruyama, S., Terabayashi, M., Fujioka, K., 1989. Origin and emplacement of ophiolite: A review. Journal of Geography Japan 98, 133-163 (in Japanese 
with English Abstract).

Minoura, N., Kumano, S., Kito, N., Kamata, K., Kato, M., 1982. Lower Cretaceous deposits at Nunobe, Central Hokkaido. Chikyu-Kagaku 36, 348-350 (in Japanese with English Abstract).

Miyashiro, A., 1973. The Troodos ophiolitic complex was probably formed in an island arc. Earth and Planetary Science Letters 19, 218-224.

Nakanishi, M., Tamaki, K., Kobayashi, K., 1992. Magnetic anomaly lineations from the Late Jurassic to Early Cretaceous in the west-central Pacific Ocean. Geophysical Journal International 109, 701-710.

Niida, K., 1992. Basalts and dolerites in the Sorachi-Yezo Belt, central Hokkaido, Japan. Journal of the Faculty of Science, Hokkaido University 23(Series IV), 301-319.

Niida, K., Kito, N., 1986. Cretaceous arc-trench systems in Hokkaido. In: Editorial committee of geology and tectonics of Hokkaido (Eds.), Geology and Tectonics of Hokkaido. Monograph of the Association for the Geological Collaboration in Japan 31, pp. 379-402 (in Japanese with English Abstract).

Okada, H., 1974. Migration of ancient arc-trench systems. In: Dott, Jr. R. H., Shaver, R. H. (Eds.), Modern and ancient geosynclinal sedimentation. Society of Economic Paleontologists and Mineralogists Special Publication No. 19, pp. 311-320

Pearce, A.J., Norry, M.J., 1979. Petrogenetic implications of Ti, Zr, Y, and Nb variations in volcanic rocks. Contributions to Mineralogy and Petrology 69, $33-47$.

Reynaud, C., Jaillard, E., Lapierre, H., Mamberti, M., Mascle, G.H., 1999. Oceanic 
plateau and island arcs of southwestern Ecuador: their place in the geodynamic evolution of South America. Tectonophysics 30, 235-254.

Shinjo, R., 1999. Geochemistry of high Mg andesites and the tectonic evolution of the Okinawa Trough - Ryukyu arc system. Chemical Geology 157, 69-88.

Sun, S.-s., McDonough, W.F., 1989. Chemical and isotopic systematics of oceanic basalts: implications for mantle composition and processes. In: Sanders, A. D., Norry, M. J. (Eds.), Magmatism in the Ocean Basins. Geological Society Special Publication 42, pp. 313-345.

Takashima, R., Yoshida, T., Nishi, H., 2001. Stratigraphy and sedimentary environments of the Sorachi and Yezo Groups in the Yubari-Ashibetsu area, Hokkaido, Japan. Journal of the Geological Society of Japan 107, 1-20 (in Japanese with English Abstract).

Tamura, A., Makita, M., Arai, S., 1999. Petrogenesis of ultramafic rocks in the Kamuikotan belt, Hokkaido, northern Japan. Memoirs of Geological Society of Japan 52, 53-68 (in Japanese with English Abstract).

Tatsumi, Y., 1981. Melting experiments on a high-magnesian andesite. Earth and Planetary Science Letters 54, 357-365.

Tatsumi, Y., 1982. Origin of high-magnesian andesite in the Setouchi volcanic belt, southwest Japan, II. Melting phase relations at high pressures. Earth and Planetary Science Letters 60, 305-317.

Tatsumi, Y., Maruyama, S., 1989. Boninites and high-Mg andesites: tectonics and petrogenesis. In: Crawford, A. J. (Eds.), Boninites and Related Rocks. Unwin Hyman, London, pp. 50-71.

Wood, D.A., 1980. The application of a Th-Hf-Ta diagram to problems of 
tectonomagmatic classification and to establishing the nature of crustal contamination of basaltic lavas of the British Tertiary volcanic province. Earth and Planetary Science Letters 50, 11-30. 


\section{Captions}

Figure 1: Simple geological map showing the distribution of the Mesozoic formations of Hokkaido Island, Japan. A double lined frame shows the study area (Fig. 3), the bold solid lines represent the boundaries of the tectonostratigraphic terranes, and the broken line marks the sub-terrane boundary within the Sorachi-Yezo terrane.

Figure 2: Summary of the Mesozoic tectonostratigraphic sequence of the eastern sub-terrane of the Sorachi-Yezo terrane. Note that the Gokurakudaira Formation constitutes the uppermost unit of the Horokanai Ophiolite as well as the lowermost formation of the Sorachi Group.

Figure 3: Geological map and structural profile sections of the southern central Hokkaido Island region. Note the development of the north-south trending faults, folds and zonal distribution of the Gokurakudaira Formation.

Figure 4: Generalized isochronous stratigraphic nomenclature of the Sorachi Group for the five sections studied in this region.

Figure 5: Photomicrographs of the greenstones of the Gokurakudaira Formation, and sedimentary rocks of the Hachimoriyama Tuff and Shinpaizawa Sandstone Members. (A) aphyric basalt of type 1 (Zone I); (B) olivine-phyric andesite of type 2 (Zone II); (C) picrite of type 3 (Zone IV); (D) dacitic volcaniclastic rocks of the Hachimoriyama Tuff Member (Zone IV); (E) andesitic volcaniclastic rocks of the Hachimoriyama Tuff Member (Zone IV); (F) arkosic sandstone of the Shinpaizawa Sandstone Member (Zone IV). Ol: olivine; sp: spinel; pl: plagioclase; qz: quartz.

Figure 6: Sedimentary sequence of the Hachimoriyama Tuff Member and the 
Shinpaizawa Sandstone Member of the western slope of the Yubari Range area (Zone IV).

Figure 7: (A) Variation diagrams showing $\mathrm{SiO}_{2}$ vs. $\mathrm{MgO}$; (B) Variation diagrams showing $\mathrm{SiO}_{2}$ vs. Fe*O/MgO; (C) Discriminant diagrams showing $\mathrm{FeO} * \mathrm{MgO}$ vs. $\mathrm{TiO}_{2}$ (Kimura et al., 1994); (D) Discriminant diagrams for $\mathrm{Hf} / 3-\mathrm{Th}-\mathrm{Ta}$ (Wood, 1980); (E) Discriminant diagrams for Zr-Zr/Y (Pearce and Norry, 1979). BABB: back-arc basin basalts; OFB: ocean-floor basalts; OIT: ocean island tholeiites; OIA: ocean island alkalic basalts; SSZ: suprasubduction zone basalts; WPB: within-plate basalts; IAT: island arc tholeiites

Figure 8: Incompatible trace elements abundances normalized to N-MORB values of Sun and McDonough (1989). The relative depletion in $\mathrm{Nb}$ and $\mathrm{Ta}$ and the enrichment in LILE are recognized for the fractionated aphyric tholeiite and volcanic fragments of the Hachimoriyama Tuff Member.

Figure 9: Discriminant diagrams of chrome spinel from the picrite and the high-Mg basalt-andesite. (A) Discriminant diagrams for $\mathrm{Fe}^{3+} /\left(\mathrm{Cr}+\mathrm{Al}+\mathrm{Fe}^{3+}\right)$ vs. $\mathrm{TiO}_{2}$ (Arai, 1992); (B) Discriminant diagrams for $\mathrm{Cr} /(\mathrm{Cr}+\mathrm{Al})$ vs. $\mathrm{TiO}_{2}$ (Arai, 1992)

Figure 10: A model for the evolution of the Horokanai Ophiolite.

Table 1: Representative analyses of the greenstones and volcanic fragments of the Gokurakudaira Formation.

Table 2: Analyses of the chrome spinel from the greenstones of the Gokurakudaira Formation. 


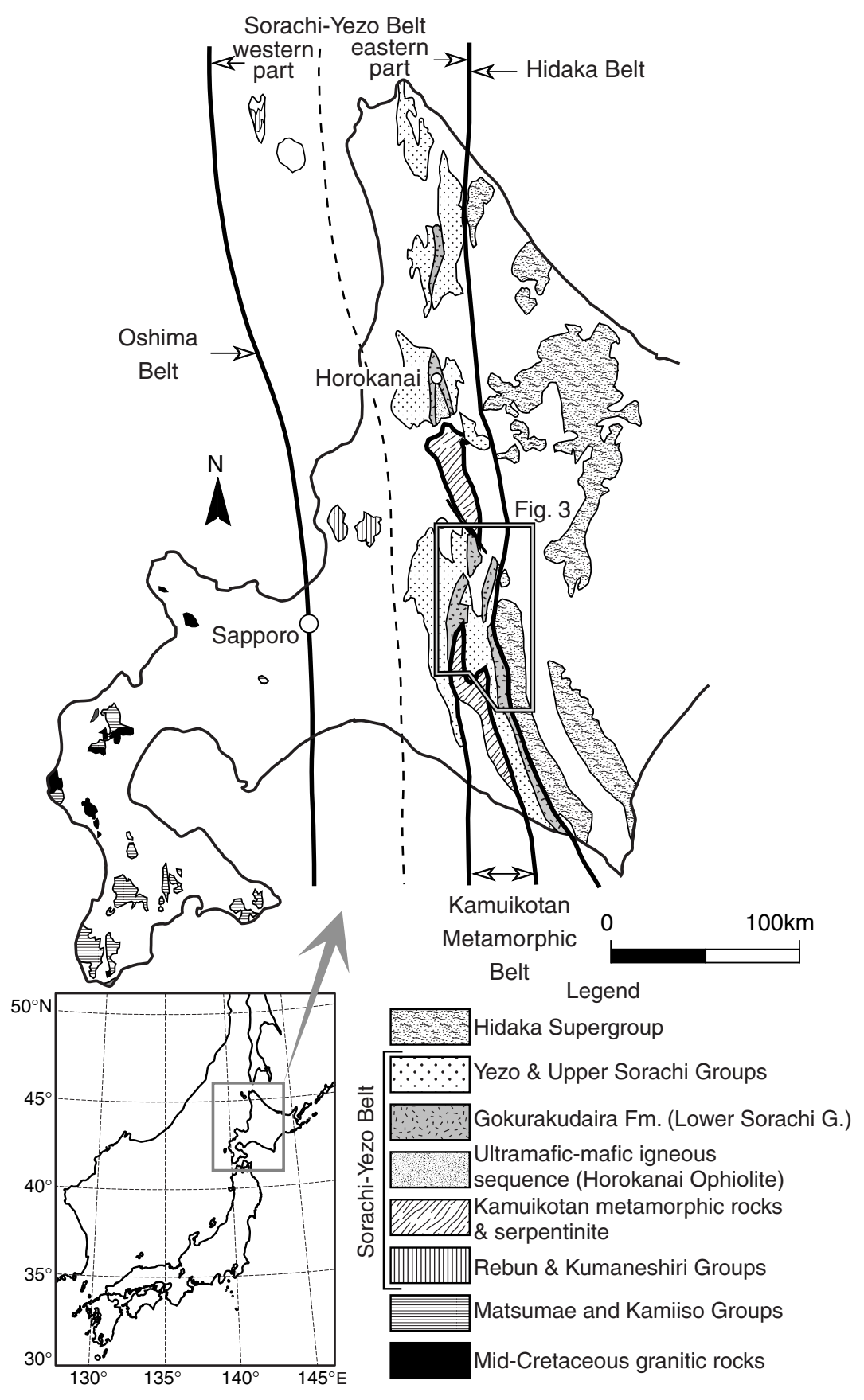

Takashima et al., Figure 1 


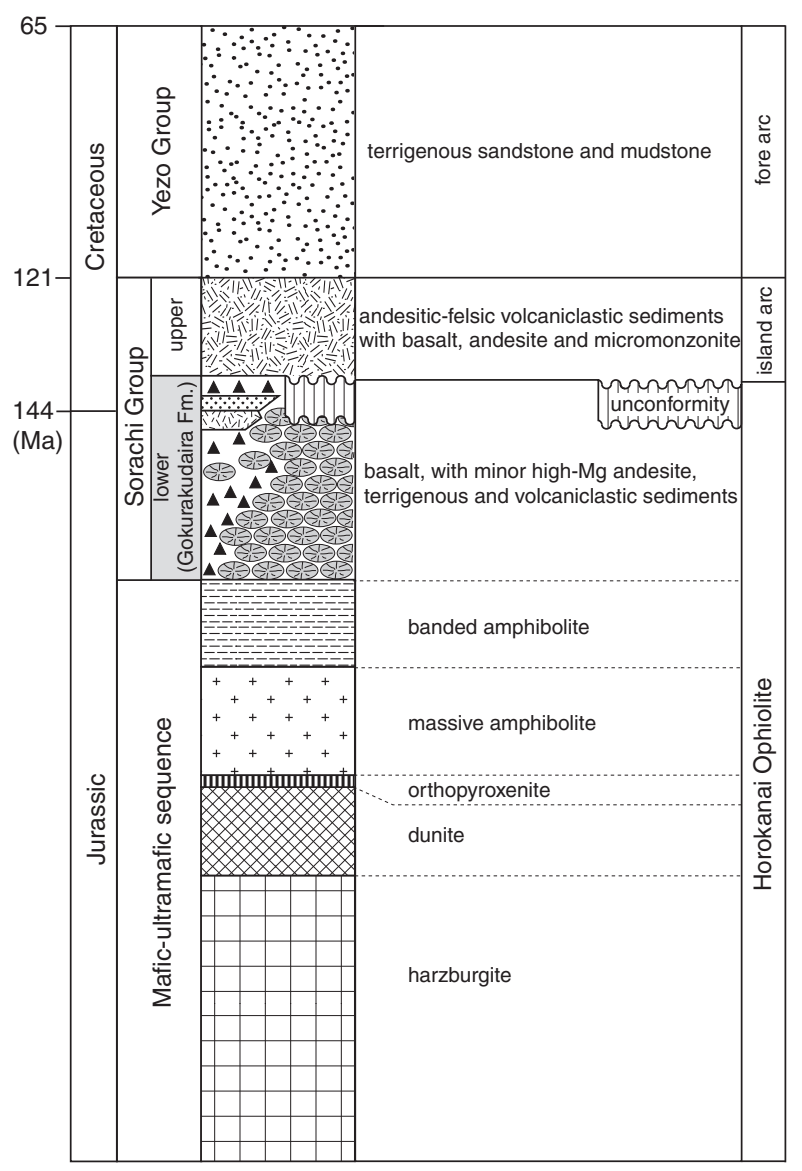

Takashima et al., Figure 2 


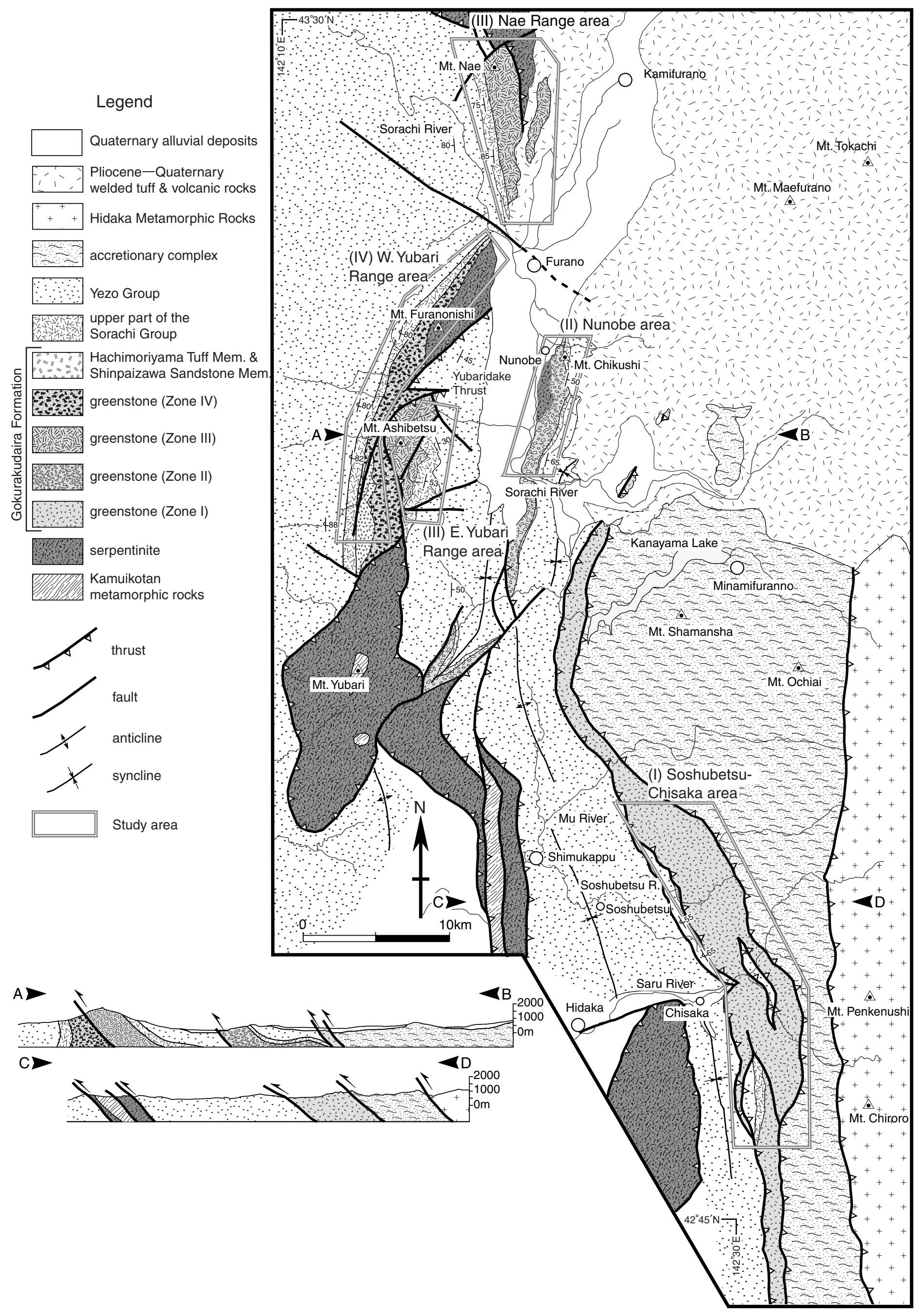

Takashima et al., Figure 3 


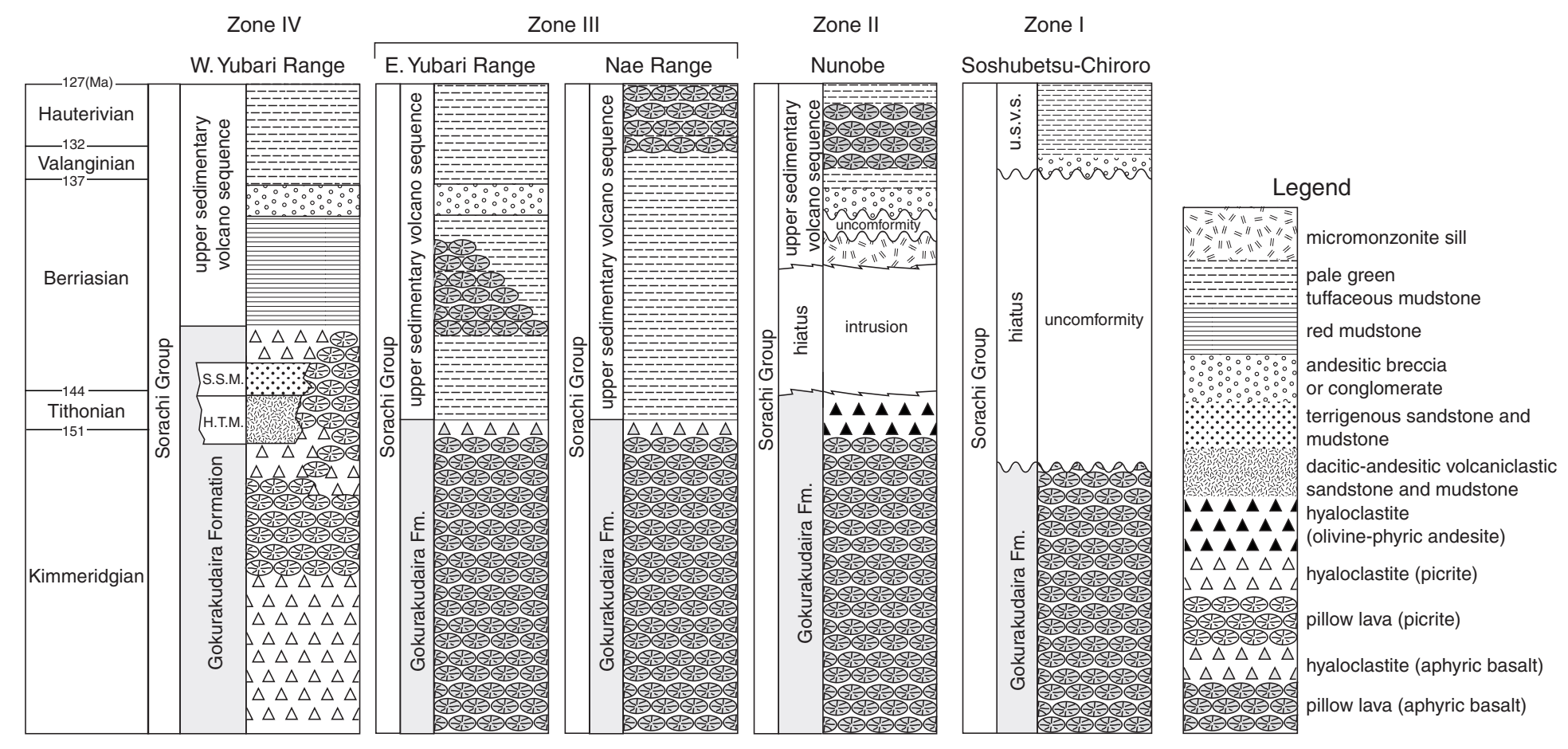



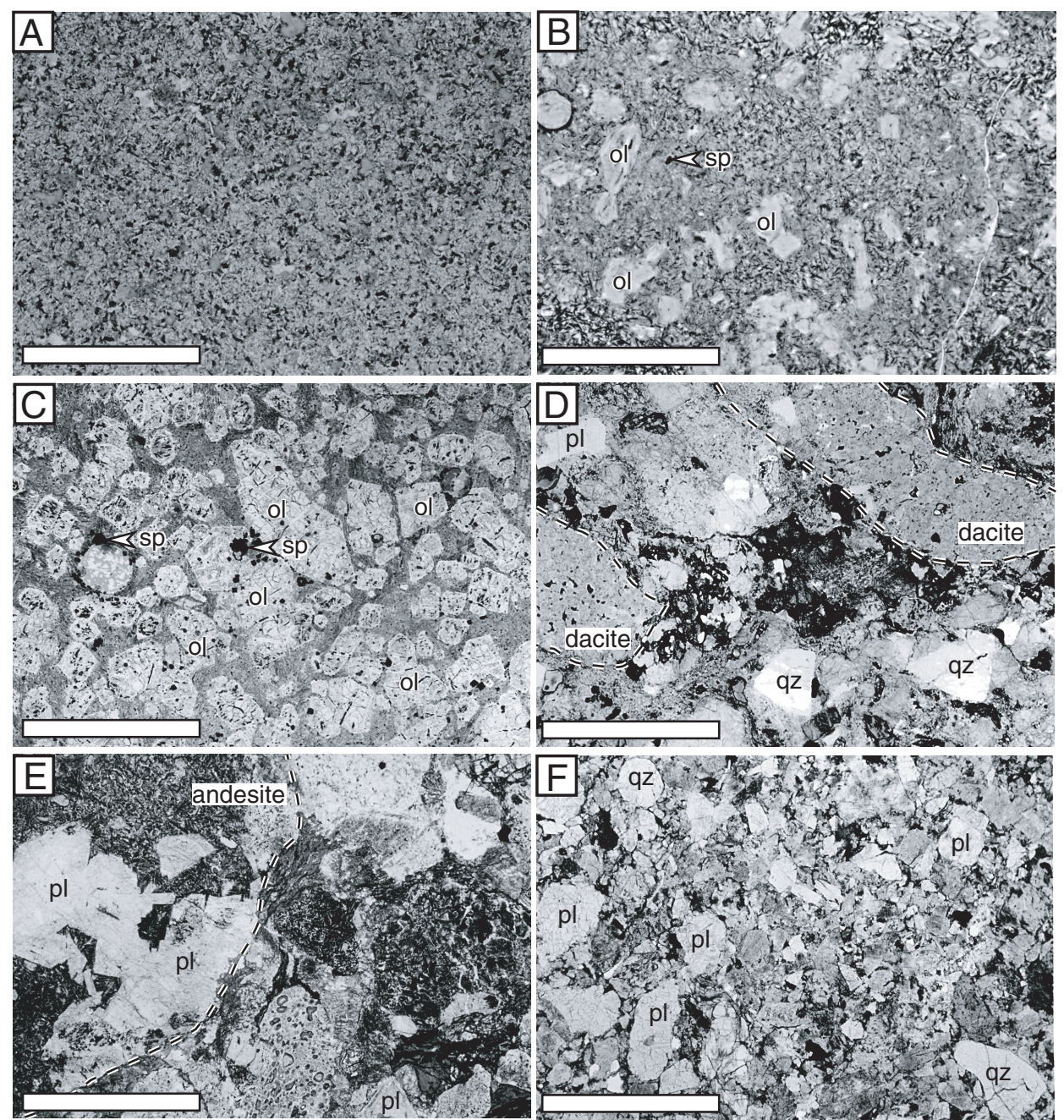

Scale bar: $2 \mathrm{~mm}$ 


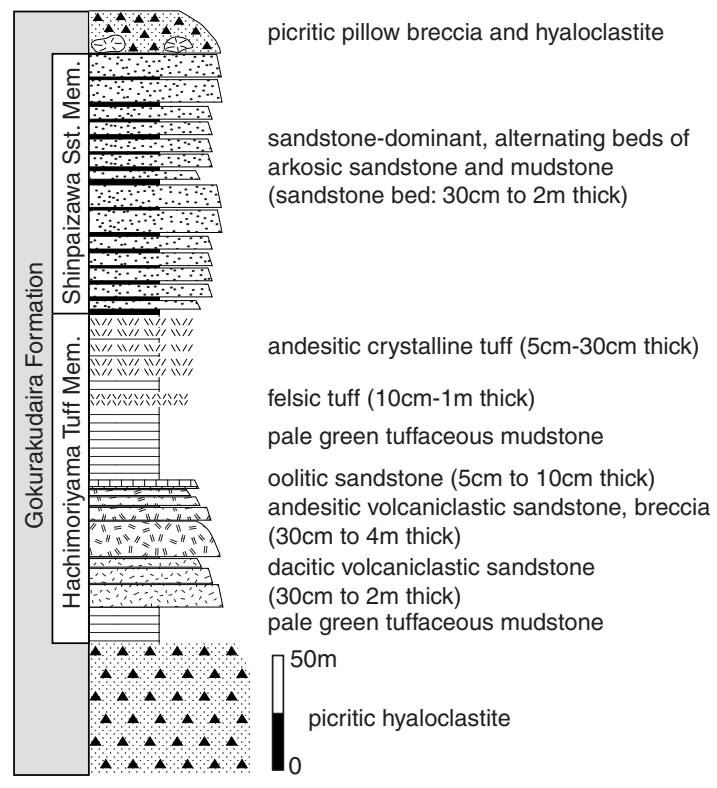

Takashima et al., Figure 6 


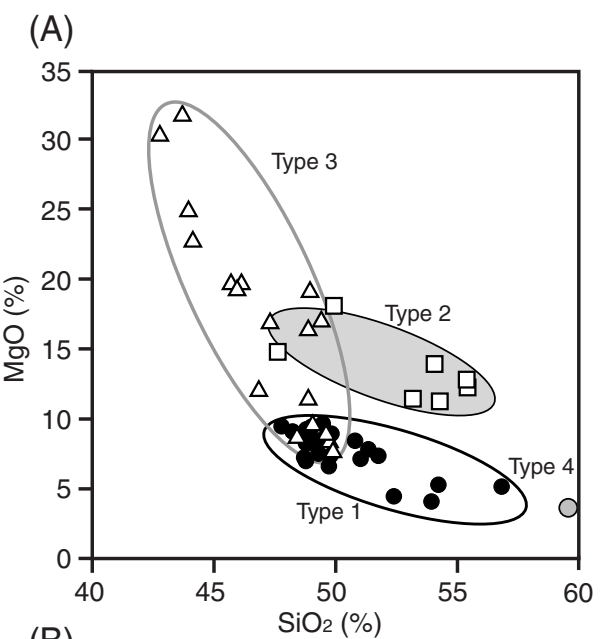

(D)

(B)

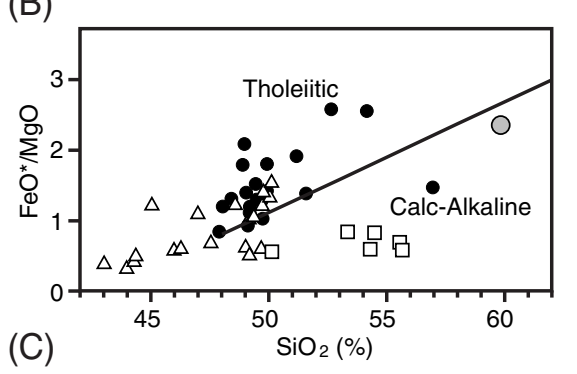

(C)
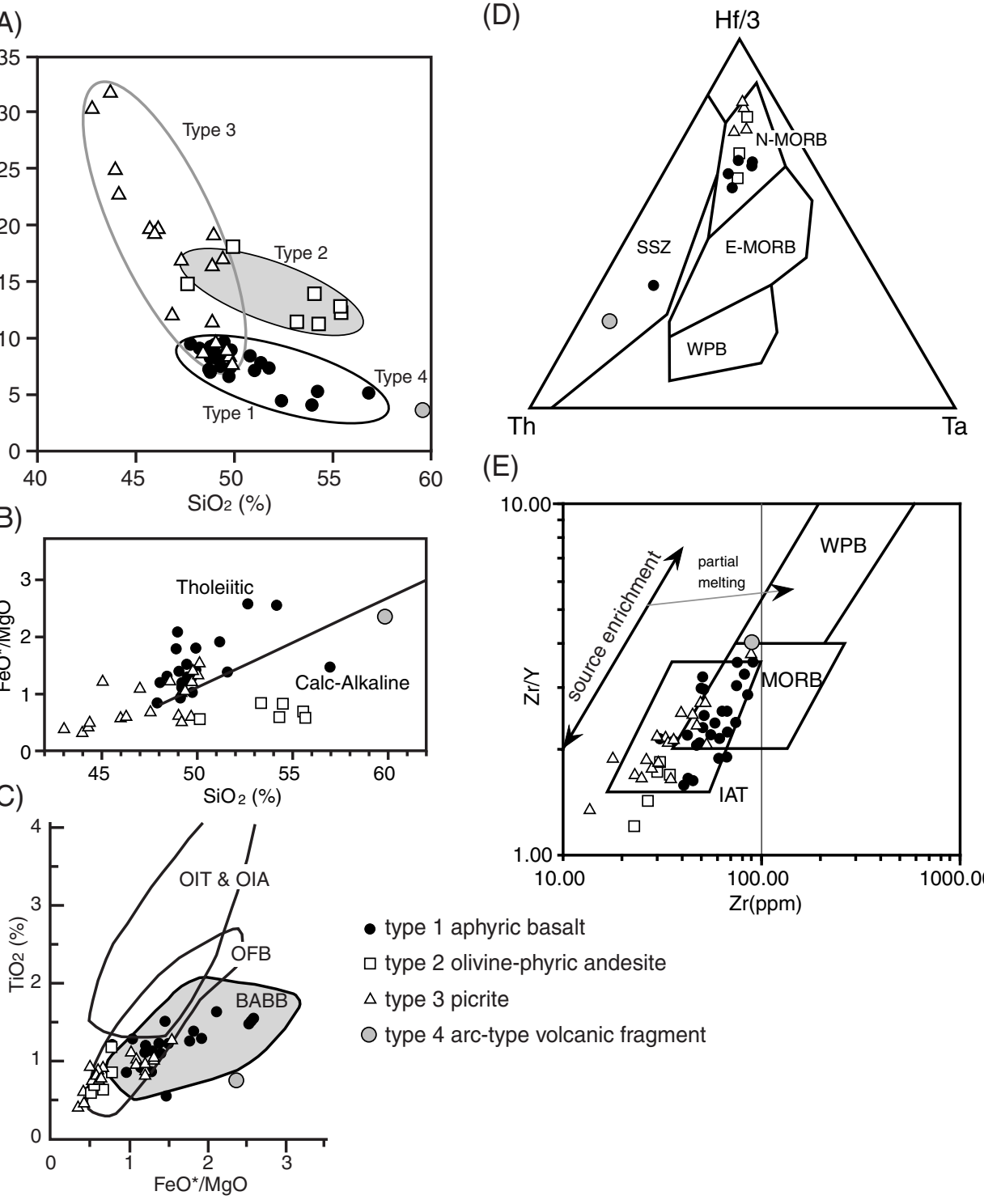

(E)

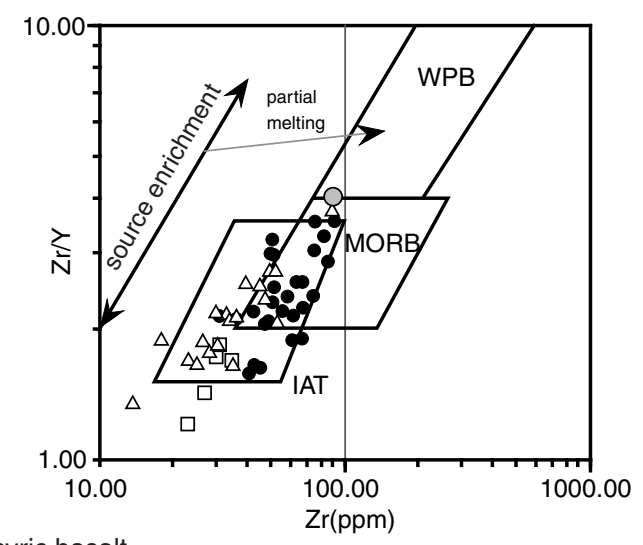

- type 1 aphyric basalt

$\square$ type 2 olivine-phyric andesite

$\triangle$ type 3 picrite

O type 4 arc-type volcanic fragment

Takashima et al., Figure 7 


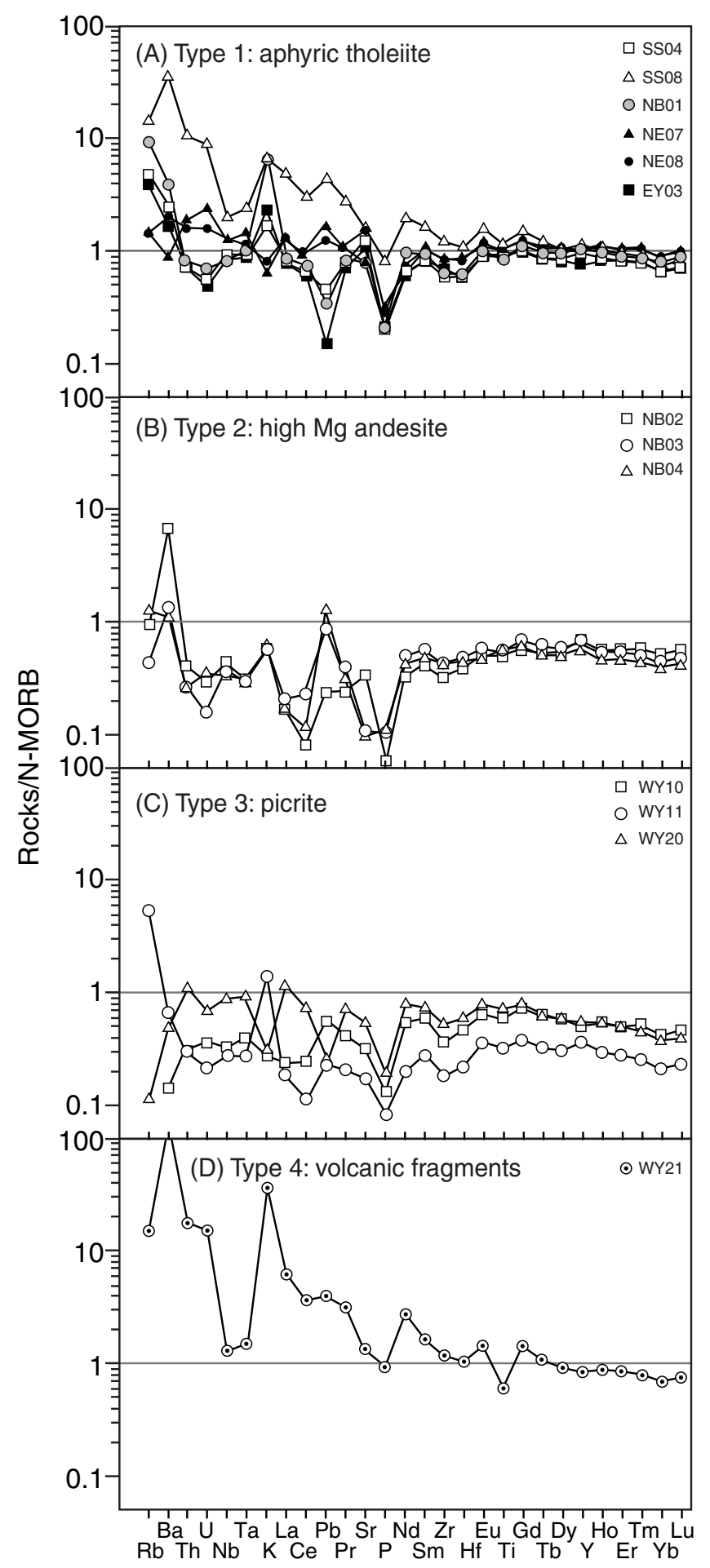

Takashima et al., Figure 8 
(A)

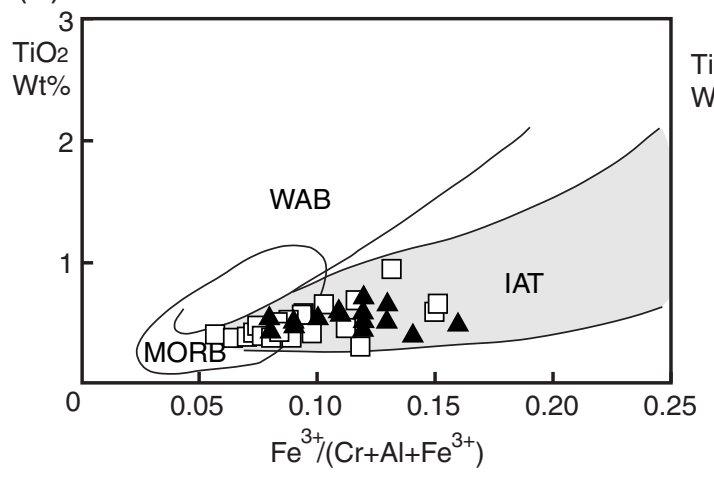

(B)

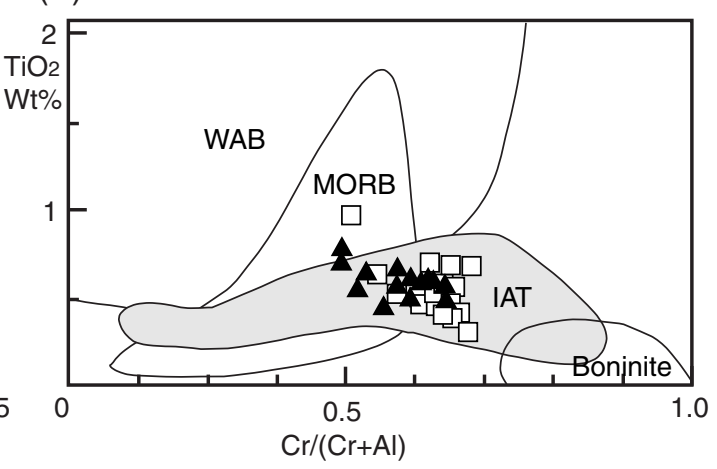



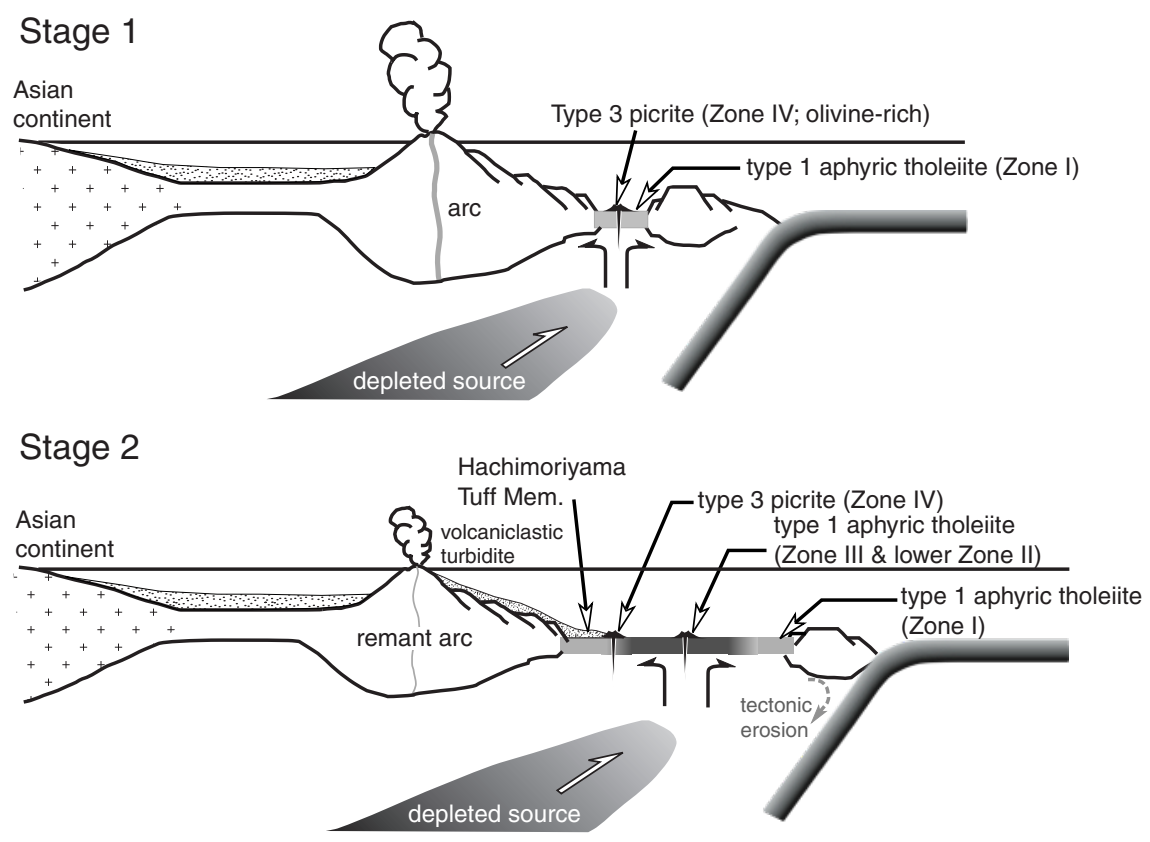

Stage 3

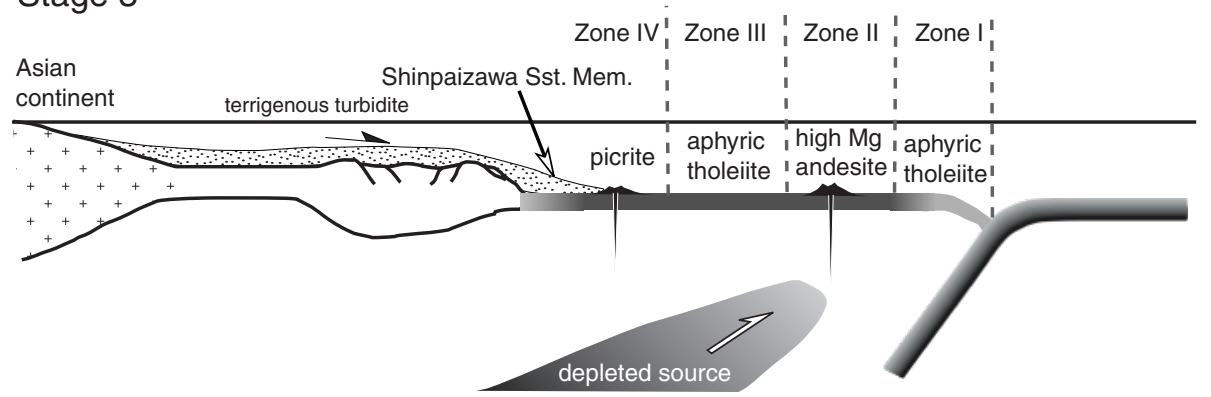




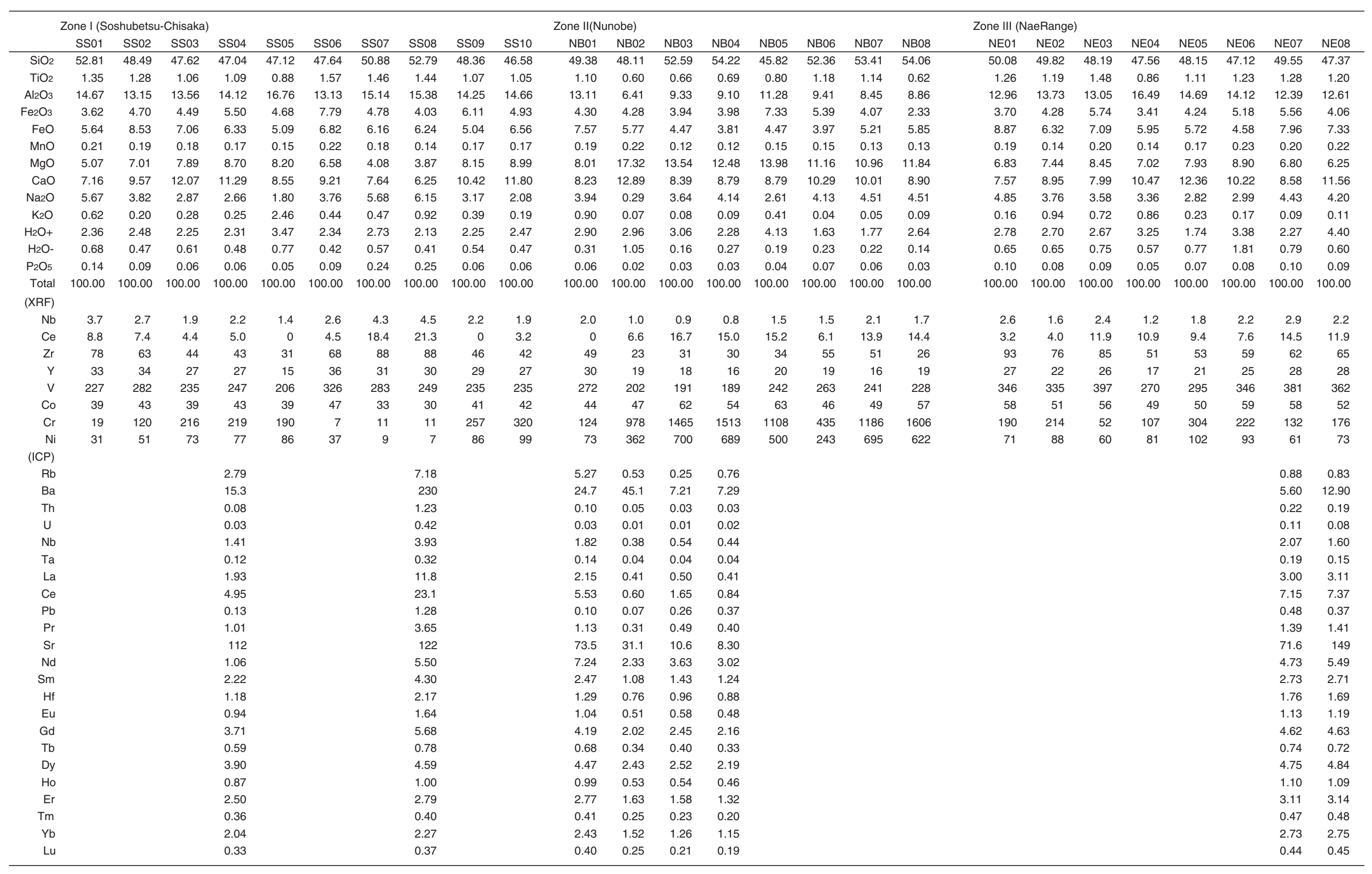


Zone III (Eastern Yubari Range)

Zone IV (Western Yubari Range)

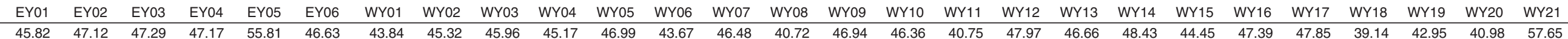

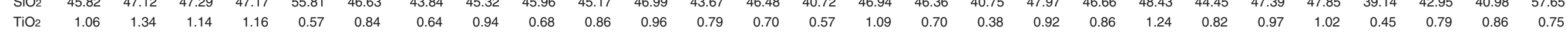

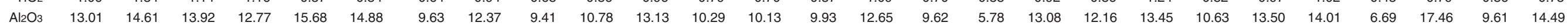

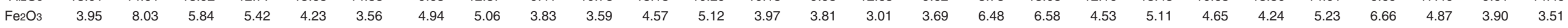

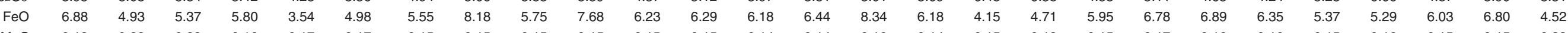

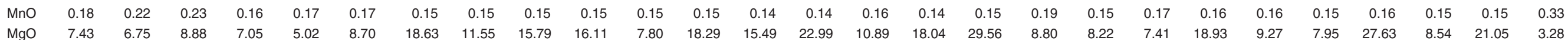

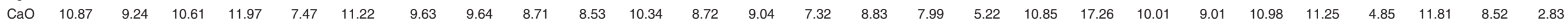

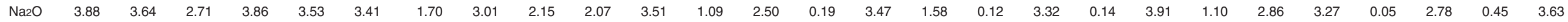

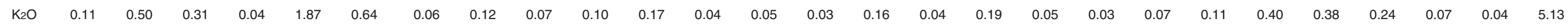

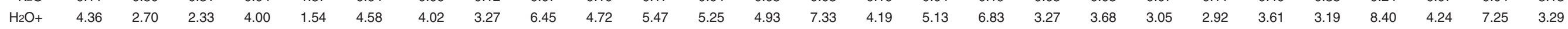

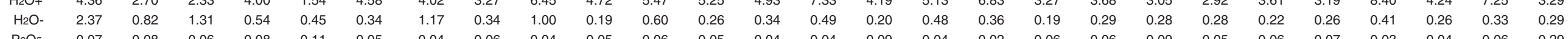

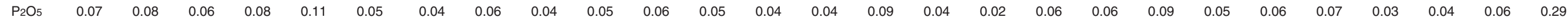

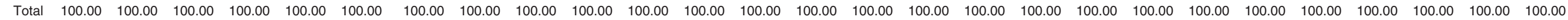
(XRF)

\begin{tabular}{|c|c|c|c|c|c|c|c|c|c|c|c|c|c|c|c|c|c|c|c|c|c|c|c|c|c|c|c|}
\hline $\mathrm{Nb}$ & 2.0 & 2.6 & 2.0 & 2.1 & 1.7 & 1.2 & 0.8 & 1.0 & 0.6 & 0.3 & 1.9 & 0.7 & 0.6 & 0.8 & 2.7 & 0.8 & 0.6 & 1.9 & 1.3 & 2.7 & 0.4 & 2.1 & 1.9 & 1.0 & 1.2 & 2.1 & 3.0 \\
\hline $\mathrm{Ce}$ & 5.3 & 5.8 & 5.3 & 11.9 & 3.1 & 4.8 & 4.8 & 5.1 & 2.6 & 2.0 & 0 & 7.2 & 1.5 & 1.1 & 3.6 & 1.7 & 0 & 0.3 & 9.5 & 0 & 2.2 & 3.5 & 5.9 & 6.2 & 5.2 & 2.8 & 28.3 \\
\hline $\mathrm{Zr}$ & 52 & 68 & 52 & 50 & 76 & 37 & 26 & 51 & 26 & 36 & 48 & 35 & 29 & 24 & 87 & 27 & 14 & 36 & 31 & 52 & 34 & 47 & 47 & 17 & 31 & 40 & 88 \\
\hline$Y$ & 24 & 27 & 22 & 24 & 25 & 17 & 16 & 19 & 16 & 17 & 20 & 17 & 17 & 14 & 23 & 14 & 10 & 22 & 17 & 25 & 16 & 19 & 19 & 9 & 14 & 16 & 24 \\
\hline v & 314 & 362 & 347 & 318 & 346 & 250 & 274 & 353 & 288 & 447 & 466 & 416 & 425 & 386 & 414 & 390 & 190 & 446 & 397 & 525 & 415 & 458 & 469 & 204 & 290 & 377 & 321 \\
\hline Co & 53 & 56 & 55 & 55 & 57 & 76 & 82 & 69 & 69 & 81 & 55 & 85 & 74 & 101 & 62 & 82 & 111 & 55 & 46 & 56 & 86 & 59 & 52 & 119 & 65 & 93 & 28 \\
\hline $\mathrm{Cr}$ & 216 & 70 & 228 & 156 & 193 & 298 & 1739 & 958 & 1716 & 1505 & 316 & 1790 & 1618 & 2865 & 592 & 1852 & 3444 & 246 & 373 & 109 & 1701 & 461 & 401 & 1878 & 267 & 2059 & 8 \\
\hline $\mathrm{Ni}$ & 98 & 58 & 90 & 81 & 85 & 137 & 838 & 458 & 698 & 636 & 98 & 792 & 645 & 1332 & 249 & 792 & 1550 & 112 & 137 & 74 & 796 & 154 & 108 & 1649 & 242 & 939 & 10 \\
\hline \multicolumn{28}{|l|}{ (ICP) } \\
\hline $\mathrm{Rb}$ & & & 2.21 & & & & & & & & & & & & & 0.00 & 3.08 & & & & & & & & & 0.07 & 8.90 \\
\hline $\mathrm{Ba}$ & & & 11.3 & & & & & & & & & & & & & 0.98 & 4.29 & & & & & & & & & 3.09 & 1096 \\
\hline Th & & & 0.09 & & & & & & & & & & & & & 0.04 & 0.04 & & & & & & & & & 0.13 & 2.19 \\
\hline U & & & 0.02 & & & & & & & & & & & & & 0.02 & 0.01 & & & & & & & & & 0.03 & 0.71 \\
\hline $\mathrm{Nb}$ & & & 1.27 & & & & & & & & & & & & & 0.71 & 0.43 & & & & & & & & & 1.86 & 3.28 \\
\hline Ta & & & 0.12 & & & & & & & & & & & & & 0.05 & 0.04 & & & & & & & & & 0.12 & 0.20 \\
\hline La & & & 1.91 & & & & & & & & & & & & & 0.60 & 0.47 & & & & & & & & & 2.82 & 15.6 \\
\hline $\mathrm{Ce}$ & & & 4.55 & & & & & & & & & & & & & 1.83 & 0.85 & & & & & & & & & 5.60 & 28.3 \\
\hline $\mathrm{Pb}$ & & & 0.05 & & & & & & & & & & & & & 0.17 & 0.07 & & & & & & & & & 0.08 & 1.19 \\
\hline $\operatorname{Pr}$ & & & 0.97 & & & & & & & & & & & & & 0.54 & 0.27 & & & & & & & & & 0.96 & 4.14 \\
\hline $\mathrm{Sr}$ & & & 106 & & & & & & & & & & & & & 30.3 & 16.7 & & & & & & & & & 48.2 & 132 \\
\hline $\mathrm{Nd}$ & & & 1.56 & & & & & & & & & & & & & 4.07 & 1.47 & & & & & & & & & 5.76 & 20.2 \\
\hline $\mathrm{Sm}$ & & & 2.16 & & & & & & & & & & & & & 1.60 & 0.77 & & & & & & & & & 1.89 & 4.35 \\
\hline $\mathrm{Hf}$ & & & 1.18 & & & & & & & & & & & & & 0.97 & 0.46 & & & & & & & & & 1.22 & 2.20 \\
\hline $\mathrm{Eu}$ & & & 0.97 & & & & & & & & & & & & & 0.67 & 0.37 & & & & & & & & & 0.82 & 1.50 \\
\hline $\mathrm{Gd}$ & & & 3.65 & & & & & & & & & & & & & 2.67 & 1.42 & & & & & & & & & 2.97 & 5.44 \\
\hline $\mathrm{Tb}$ & & & 0.58 & & & & & & & & & & & & & 0.41 & 0.22 & & & & & & & & & 0.44 & 0.72 \\
\hline Dy & & & 3.70 & & & & & & & & & & & & & 2.63 & 1.43 & & & & & & & & & 2.65 & 4.33 \\
\hline Ho & & & 0.84 & & & & & & & & & & & & & 0.54 & 0.30 & & & & & & & & & 0.55 & 0.90 \\
\hline $\mathrm{Er}$ & & & 2.45 & & & & & & & & & & & & & 1.53 & 0.83 & & & & & & & & & 1.50 & 2.54 \\
\hline $\mathrm{Tm}$ & & & 0.36 & & & & & & & & & & & & & 0.23 & 0.12 & & & & & & & & & 0.21 & 0.37 \\
\hline $\mathrm{Yb}$ & & & 1.95 & & & & & & & & & & & & & 1.29 & 0.67 & & & & & & & & & 1.16 & 2.16 \\
\hline Lu & & & 0.33 & & & & & & & & & & & & & 0.22 & 0.11 & & & & & & & & & 0.18 & 0.35 \\
\hline
\end{tabular}




\section{EPMA Mineral Data}

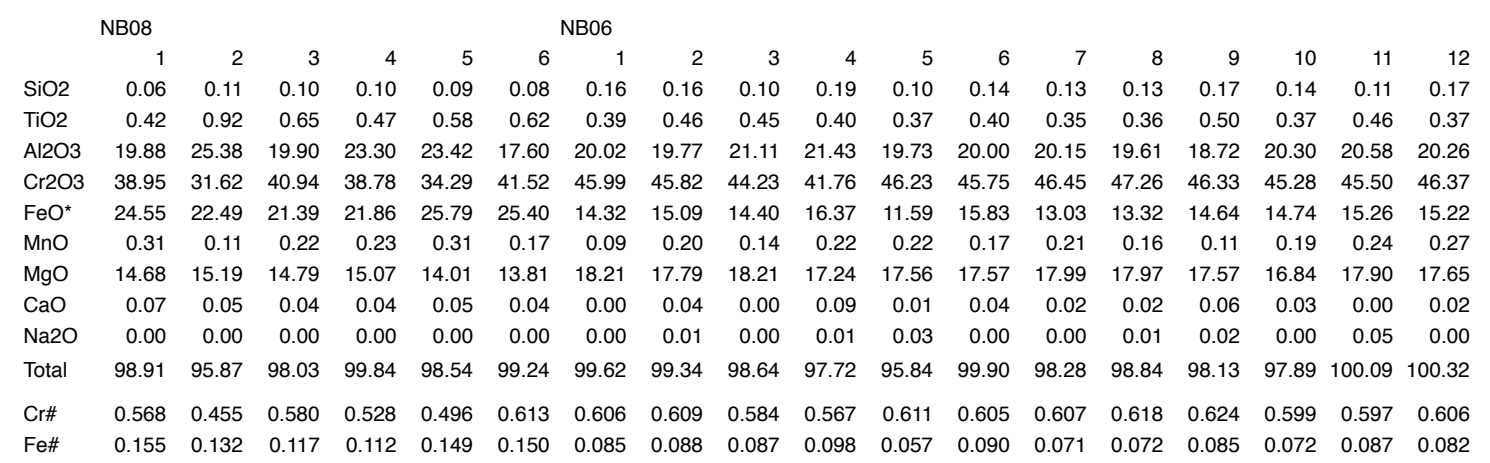

NB04

\begin{tabular}{|c|c|c|c|c|c|c|c|c|c|c|c|c|c|c|c|c|c|}
\hline & & & & & & & & & & & & & & & & & \\
\hline & & & & & & & & & & & & & & 15 & & & \\
\hline 0.11 & 0.13 & 0.16 & 0.16 & 0.16 & 0.12 & 0.16 & 0.16 & 0.08 & 0.11 & 0.10 & 0.11 & 0.12 & 0.11 & 0.15 & 0.12 & 0.08 & 0.13 \\
\hline 0.37 & 0.41 & 0.46 & 0.35 & 0.38 & 0.38 & 0.43 & 0.40 & 0.25 & 0.62 & 0.53 & 0.44 & 0.39 & 0.34 & 0.33 & 0.33 & 0.43 & 0.39 \\
\hline 20.04 & 20.00 & 19.90 & 19.75 & 20.07 & 19.21 & 20.62 & 20.37 & & 17.50 & 19.66 & 22.39 & 19.71 & 18.99 & 19.26 & 20.03 & 19.96 & 19.46 \\
\hline 45.37 & 44.78 & 45.98 & 46.60 & 44.62 & 45.58 & 46.44 & 46.13 & 46.09 & 47.86 & 45.27 & 44.03 & 48.11 & 48.42 & 46.93 & 48.14 & 45.75 & 46.53 \\
\hline 39 & 14.19 & & & & 5.27 & 14. & & & 17.2 & 16.66 & 14.88 & 14.69 & 14.60 & 12 & 13.83 & 14.91 & 15.50 \\
\hline 0.27 & 0.23 & 0.29 & 0.14 & 0. & 0.23 & 0.26 & 0.2 & 0.16 & 0.17 & 0.22 & 0.18 & 0.19 & 0.19 & 0.26 & 0.14 & 0.21 & 0.18 \\
\hline 17.66 & 18.15 & 17.81 & 16.61 & 15.62 & 15.90 & 17.66 & 17.45 & 16.41 & 17.25 & 17.00 & 18.35 & 18.21 & 17.68 & 17.58 & 17.59 & 17.99 & 17.87 \\
\hline & & & & & & & & & & 0. & & & & & & & 0.04 \\
\hline 0.02 & 0.00 & 0.06 & & & 0.01 & 0.00 & & & 0.01 & 0.00 & 0.01 & 0.00 & 0.02 & 0.01 & 0.00 & 0.00 & 0.02 \\
\hline 98.22 & 97.90 & 99.50 & 99.85 & 99.19 & 97.69 & 100.23 & 99.64 & 99.29 & 100.79 & 99.47 & 100.40 & 101.41 & 100.36 & 99.98 & 100.18 & 99.33 & 100.11 \\
\hline & & & & & & & & & & & & & & & & & \\
\hline 0 & 090 & 085 & 0.077 & 086 & & & & 118 & & & & 08 & $0 / 8$ & .088 & 0.064 & 0.090 & \\
\hline
\end{tabular}

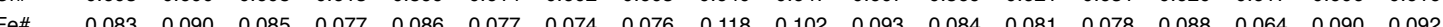

WY10

$\begin{array}{rrrrrrrrrrrrrrrrrr} & 1 & 2 & 3 & 4 & 5 & 6 & 1 & 2 & 3 & 4 & 5 & 6 & 7 & 8 & 9 & 10 & 11\end{array}$

$\begin{array}{llllllllllllllllll}\text { TiO2 } & 0.32 & 0.10 & 0.13 & 0.13 & 0.15 & 0.14 & 0.13 & 0.01 & 0.07 & 0.09 & 0.14 & 0.14 & 0.13 & 0.12 & 0.08 & 0.12 & 0.12 \\ & 0.50 & 0.51 & 0.52 & 0.52 & 0.53 & 0.43 & 0.36 & 0.47 & 0.40 & 0.46 & 0.57 & 0.48 & 0.70 & 0.62 & 0.50\end{array}$

$\begin{array}{llllllllllllllllll}\mathrm{Al} 2 \mathrm{O} 3 & 19.40 & 23.26 & 20.01 & 19.20 & 19.40 & 20.05 & 21.91 & 22.23 & 24.83 & 24.53 & 19.20 & 19.06 & 24.85 & 22.45 & 27.79 & 27.00 & 20.73\end{array}$

$\begin{array}{llllllllllllllllll}\mathrm{Cr} 2 \mathrm{O} 3 & 43.96 & 38.98 & 44.98 & 45.62 & 40.39 & 43.29 & 40.36 & 40.23 & 39.03 & 32.34 & 45.25 & 43.09 & 34.01 & 37.88 & 31.97 & 32.00 & 41.77\end{array}$

$\begin{array}{llllllllllllllllll}\mathrm{FeO}^{*} & 13.71 & 19.03 & 16.16 & 15.58 & 16.80 & 16.32 & 20.91 & 21.81 & 25.87 & 25.41 & 17.43 & 21.50 & 20.52 & 21.59 & 21.06 & 22.50 & 22.05\end{array}$

$\begin{array}{lllllllllllllllllll}\mathrm{MnO} & 0.13 & 0.23 & 0.22 & 0.22 & 0.09 & 0.23 & 0.13 & 0.27 & 0.30 & 0.29 & 0.20 & 0.65 & 0.27 & 0.15 & 0.13 & 0.20 & 0.20\end{array}$

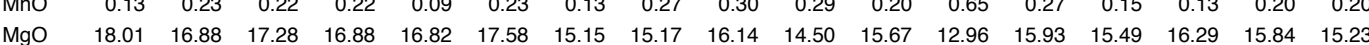

$\begin{array}{llllllllllllllllll}\mathrm{CaO} & 0.02 & 0.01 & 0.05 & 0.05 & 0.00 & 0.53 & 0.15 & 0.17 & 16.14 & 14.50 & 15.67 & 12.96 & 15.93 & 15.49 & 16.29 & 15.84 & 15.23\end{array}$

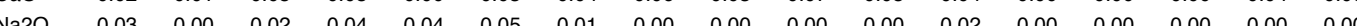

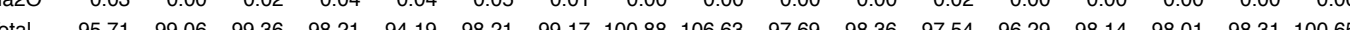

$\begin{array}{llllllllllllllllll}\text { Cr\# } & 0.603 & 0.529 & 0.601 & 0.615 & 0.583 & 0.592 & 0.553 & 0.548 & 0.513 & 0.469 & 0.613 & 0.603 & 0.479 & 0.531 & 0.436 & 0.443 & 0.575\end{array}$

$\begin{array}{lllllllllllllllllllll}\text { Fe\# } & 0.093 & 0.113 & 0.091 & 0.084 & 0.115 & 0.104 & 0.106 & 0.116 & 0.145 & 0.156 & 0.084 & 0.093 & 0.124 & 0.125 & 0.119 & 0.131 & 0.119\end{array}$ 